\title{
Vaccine market and production capabilities in the Americas
}

\author{
Esteban Ortiz-Prado ${ }^{1,2^{*}}$ (D), Estefanía Espín ${ }^{1}$, Jorge Vásconez ${ }^{1}$, Nathalia Rodríguez-Burneo ${ }^{1}$, Nikolaos C. Kyriakidis ${ }^{1}$ and \\ Andrés López-Cortés ${ }^{3,4}$
}

\begin{abstract}
In the Americas, The United States of America, Canada, Mexico, and Brazil are the top vaccine producers and the countries with the leading infrastructure for biological manufacturing. The North American countries have the most demanding legislation regulating and controlling these pharmaceuticals' distribution and production. Some Latin American countries rank in the top 20 of worldwide vaccine manufacturers, with Cuba, Brazil, México and Colombia have a self-sufficient vaccine production of $72.7 \%, 54,2 \%$; $25 \%$; and $7.7 \%$, respectively, of the national vaccine demand. On the other hand, the rest of Latin American countries cannot satisfy their demand for vaccines, and most of their efforts are associated with the distribution within their health systems rather than in transferring technology.

Based on this literature review, the results suggest an increasing growth vaccine demand, not only for their growing populations and previously established demand but also for the recently exerted pressure due to the COVID-19 pandemic.

Because the American continent has a marked inequality between the hegemonic producers of vaccines, the exporters, and those that depend heavily on importing these products, this could assert technological dependence in countries with rapid population growth and jeopardize the effectiveness of the two vaccination plans.
\end{abstract}

Keywords: Vaccines, Latin America, Market, Vaccine coverages, Economic dependence

\section{Introduction}

It is well known that vaccination against various diseases, including preventable, contagious, and life-threatening illnesses, is the best public health intervention after water sanitation. Vaccinations aim to save millions of lives by generating artificial and life-saving immunological responses [1].

Over the past few decades, mankind has experienced rapid progress in developing new vaccines, including recent novel coronavirus (COVID-19) vaccine

\footnotetext{
* Correspondence: e.ortizprado@gmail.com

'One Health Research Group, Universidad de las Américas, Quito, Ecuador Calle de los Colimes y Avenida De los Granados, 170137 Quito, Ecuador ${ }^{2}$ Department of Cell Biology, Physiology and Immunology, Universidad de Barcelona, Barcelona, Spain

Full list of author information is available at the end of the article
}

developments that added more than 200 candidates to the production pipeline (Fig. 1) [2].

Around the globe, several production plants manufactured vaccines for decades. Most of these production plants still use immunological strategies that were developed decades ago. During the nineteenth century, scientists from United States, Great Britain, France, and Germany developed strategies for inactivating a whole bacteria and developed inactivated whole-cell vaccines against plague, typhoid, and cholera. Therefore, it is helpful to contemplate the past for having a great deal of forwarding gazing with new potential vaccine production strategies. For instance, the first influenza vaccine using attenuated virus was developed in 1936, while mRNA and viral-vector-based vaccine have been developed in

(c) The Author(s). 2021 Open Access This article is licensed under a Creative Commons Attribution 4.0 International License, which permits use, sharing, adaptation, distribution and reproduction in any medium or format, as long as you give appropriate credit to the original author(s) and the source, provide a link to the Creative Commons licence, and indicate if changes were made. The images or other third party material in this article are included in the article's Creative Commons licence, unless indicated otherwise in a credit line to the material. If material is not included in the article's Creative Commons licence and your intended use is not permitted by statutory regulation or exceeds the permitted use, you will need to obtain permission directly from the copyright holder. To view a copy of this licence, visit http://creativecommons.org/licenses/by/4.0/ The Creative Commons Public Domain Dedication waiver (http://creativecommons.org/publicdomain/zero/1.0/) applies to the data made available in this article, unless otherwise stated in a credit line to the data. 


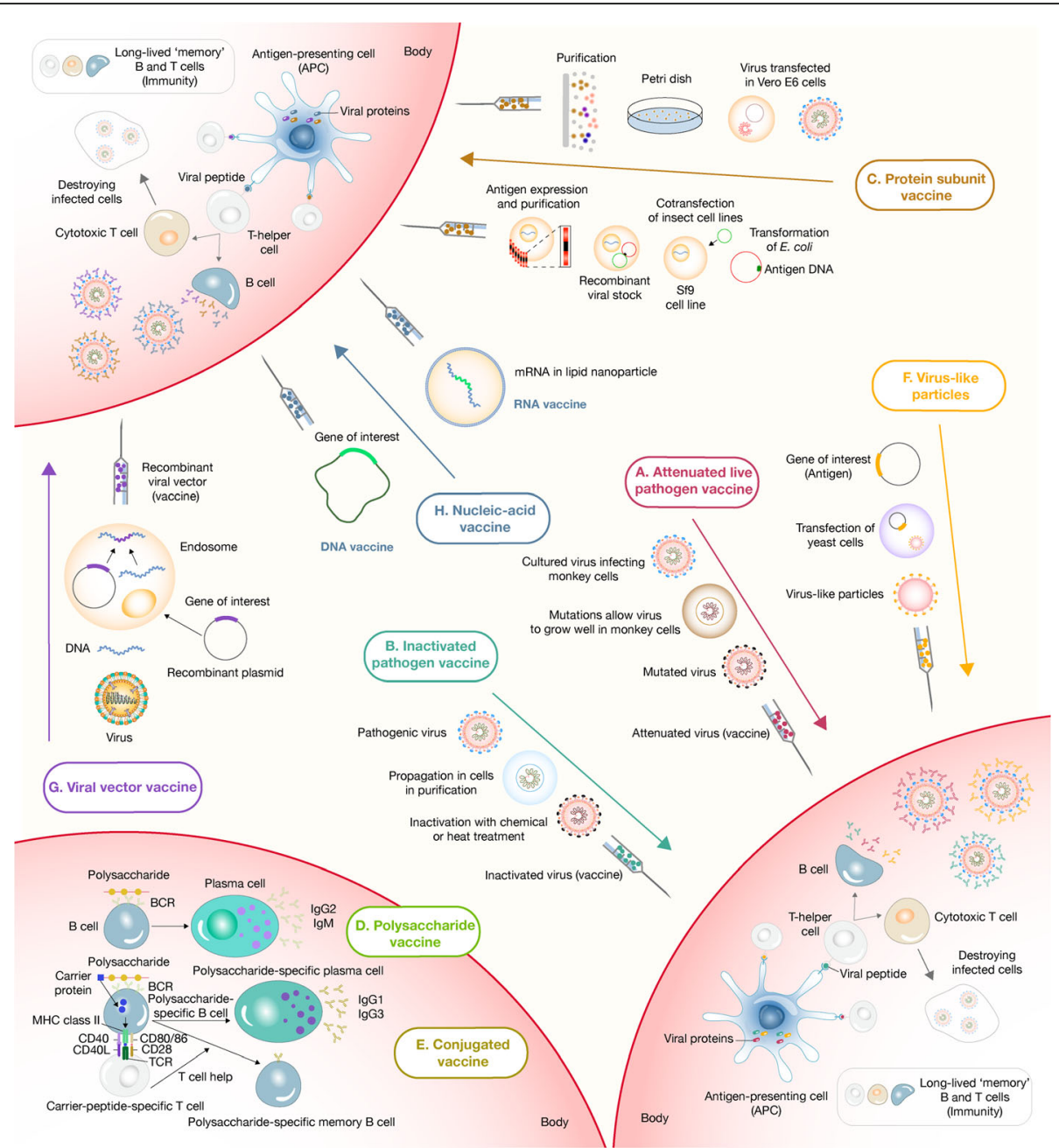

Fig. 1 Panoramic landscape of the strategies used for vaccine development and delivery. a The live attenuated vaccine strategy consists of administering a weakened form of a live pathogen. This strategy usually elicits robust and long-term memory immune responses after a single dose. $\mathbf{b}$ The inactivated pathogen vaccine strategy also consists of administering a whole pathogen, but in this case, inactivated by heat or chemical treatment. This strategy has a better safety profile but often is found to be less immunogenic. $\mathbf{c}$ In contrast with whole pathogen strategies, subunit vaccine strategies include administering only the most immunogenic antigens of a pathogen. These strategies commonly require adjuvant addition to triggering robust immune responses. Protein subunit vaccines are the most prominent members of this group. $\mathbf{d}$ Another type of subunit vaccine is polysaccharide vaccines. This strategy consists of administering long chains of sugar molecules that make up certain bacteria's surface capsules. However, polysaccharides are T-independent antigens, eliciting low quality and short-term immune responses, especially in children. e To tackle this disadvantage, conjugated vaccines were perceived. This strategy uses a molecule composed of a polysaccharide antigen fused or conjugated to a carrier-protein antigen that induces long-term immunological memory, isotype switching, and affinity maturation processes. $\mathbf{f}$ The virus-like particle strategy is the last member of the subunit vaccine group. In this case, antigens are expressed in recombinant yeast cells, vaccinia virus or tobacco mosaic virus transfected organisms, and subsequently self-assembled in virus-like particles whose size and conformation induce their capture from host antigen-presenting cells, eliciting solid immune responses postadministration. $\mathbf{g}$ The viral vector vaccine strategy consists of applying a genetically manipulated measles or adenoviral platform to express a foreign antigen to trigger robust immune responses. $\mathbf{h}$ Finally, the nucleic acid vaccine strategies (DNA and mRNA) codify the pathogen's immunogenic proteins. Once administered, the genetic material is captured by myocytes or antigen-presenting cells that use it to express and present the antigen to the host immune system

more modern plants faster than ever before, as is the case of the latest COVID-19 vaccines [3-5] (Fig. 1).

Although it appears that many countries have sufficient national vaccine production capacities, this differs significantly from reality. Recently several countries have decreased vaccination rates below the desirable levels, jeopardizing public health strategies to reduce mortality, morbidity, and prevalence of diseases [6].

The history of vaccine production started with Edward Janner's and Louis Pasteur's innovation and immunization practices, making the development of vaccination a necessary practice for improving wealth. Nowadays, vaccine 
development requires specific industries, a robust economic situation, and significant investments [7]. Vaccine production is directed by states with a technological industry large enough to supply each country's needs. Many of these countries have an extensive potential for vaccine production, which changes the structure of a technologybased economy [8].

Enormous amounts of money have been put into programs that are trying to reduce preventable diseases, especially in developing countries [9]. Although these capital injections have managed to reduce the impacts of comorbid diseases in some of the world's most remote parts, they have not yet managed to build independent national vaccine production capacities, making these non-self-sustainable interventions a temporary solution.

Vaccine manufacturing industries are driven primarily by developed countries and production-rated economies. Therefore, most developing and low-resource countries need to import the final product and equipment for quality vaccines $[10,11]$. On top of this, pharmaceutical plants' high costs create difficulties for developing countries to manufacture vaccines or compete with existing manufacturers (Table 1).

Although the budget for vaccination programs has increased drastically over the past two decades, some countries still experience low coverages.

In this sense, it is a priority for countries to have suitable and self-sustainable policies as well as enough political will to allocate all the necessary monetary resources to maintain an adequate and constant supply of vaccines and well-established immunization programs to guarantee their distribution in those places [12].

Relocating resources and creating public policy that aims to manufacture vaccines is challenging for everyone, especially for low-and-middle-income countries. The presence of political instability, poor infrastructure, dubious regulatory frameworks, and other factors are some of the barriers to save vaccine production.

Table 1 analysis of production costs linked to the development of different vaccines [10]

\begin{tabular}{ll}
\hline Costs & Cost range \\
\hline Product development & $>500$ M USD \\
Facilities and Equipment & 50 to $700 \mathrm{M}$ USD \\
Direct Labor & $\begin{array}{l}\text { Typically, less than 25\% of the total } \\
\text { manufacturing cost }\end{array}$ \\
& Up to 45\% of the cost of raw materials and \\
Overhead & labor \\
& Simple vaccine: \\
Licensing/Regulatory and & - Evaluation fee of 25 to 100 K, and Annual \\
commercialization & fees of 4.8 K to 140 K USD \\
& Combo or Novel Vaccines: \\
& - Evaluation fee of 66.5 to 232.8 K USD, and \\
& Annual fees of 8.4 to 250 K USD \\
\hline
\end{tabular}

This review aims to identify the information available concerning the productive capacities of the American continent's different countries, including The United States of America and Canada and countries such as Bolivia, Cuba, Peru, and Ecuador.

\section{Vaccines in the Americas}

The World Health Organization (WHO) established the Expanded Program on Immunization (EPI) in 1974 to develop and expand immunization programmes throughout the world; the goal was child's immunization against tuberculosis, diphtheria, poliomyelitis, pertussis, measles, and tetanus [13]. The WHO Regional Office for the Americas (PAHO) developed an EPI in 1977 and established the Revolving Fund, a solidary and equitable mechanism to facilitate vaccine acquisition to the region's countries. The first EPI recommended the use of vaccines to protect against six diseases: tuberculosis (BCG), diphtheria, tetanus, pertussis (DTP), measles (Meas), and poliomyelitis (IPV) [14]. Vaccine development between 2000 and 2010 introduced to the EPI: combined vaccines with several antigens Diphtheria whole-cell pertussis tetanus (DwPT) - Hepatitis B (HepB) - Haemophilus influenza type b, inactivated polio vaccine (Hib) - Inactivated Polio vaccine (IPV); pneumococcal conjugate vaccine (PCV); rotavirus (RV), human papillomavirus (HPV), meningococcal (MCV), and yellow fever (YF) vaccines.

The WHO has divided vaccines into three major categories: i) traditional: Diphtheria-Tetanus (DT)-containing, MCVs, DwPT-HepB-Hib, BCG, IPV, HepB, Hepatitis A (HepA); ii) innovator: new vaccines as PCV, $\mathrm{RV}$, meningococcal conjugate vaccine (MCV4), HPV, varicella; and iii) targeted: regional and outbreak (YF). Traditional vaccines lead global market volume, and innovator vaccines drive global market value. Although a few vaccine manufacturers dominate the market (GSK, Sanofi, Serum Institute of India (SII), Microgen and Merck, Central and South American Developing Countries Vaccine Manufacturers (DCVM) supply the highest doses for this region, suggesting a preference for local producers [15].

\section{Vaccines in Canada}

Canada is one of the top producers of vaccines globally, housing several international manufacturers such as GlaxoSmithKline, Merck Canada Ltd., Novartis, Pfizer Canada (formerly Wyeth Pharmaceuticals Canada), and other producers such as Sanofi Pasteur [16]. The vaccine industry in Canada also comprises of national firms such as Solvay Pharma Inc., Medicago, Immunoaccine Inc., Variation Biotechnologies, and many more small biotech companies [17]. 
Canada has a Vaccine Industry Committee, which works to ensure the supply of vaccines and advocate equitable access as well as regulating quality and safety. This committee brings together some of the largest and most important pharmaceutical companies in the world and government institutions, and civil society [16]. The leading vaccine producers in Canada are Sanofi, which produces and manufactures DTP, BCG, IPV, DT vaccines; and GlaxoSmithKline (GSK), manufactures influenza vaccines. Manufacturers in Canada produce vaccines for both global clinical trials and/or commercial sales [17]. During 2018, vaccine sales were USD 1.822 billion [18]. Despite meeting their national vaccination program requirements with international and national commercial vaccine production and exporting USD 15.208 billion of pharmaceutical products, Canada still imported USD 69.992 billion [19].

Regulation requirements for vaccines in Canada are regulated by Health Canada, which evaluates the safety, efficacy, and quality of a vaccine based on scientific and clinical evidence. Health Canada also authorizes only vaccines that meet this requirement and then monitored the quality and post-market surveillance of vaccines. The Food and Drug Act categorizes vaccines as biological drugs, requiring more regulatory oversights and expertise and procedures for their manufacture, control, and regulation [20].

Vaccination coverage goals in Canada are part of the National Immunization Strategy objectives for 20162021. The country has a compulsory vaccination strategy for children of school-age [21]. With the implementation of the "Panorama" system, an integrated public health information system designed to help public health professionals manage vaccine inventories, immunization, investigation, outbreaks, and family health, vaccination is more accessible to the public [22]. As part of the National Immunization Strategy, Canada requires infants to receive pertussis, DTP-Hib, IPV, MMR, chickenpox, and PVC vaccines, and adolescents receive PCV and MCV4 vaccines. HepB is required for all ages [23].

Canada is one of the drivers for the discovery of new vaccines. Recently, the country produced the vaccine that targets cervical cancer caused by HPV and gastroenteritis due to retrovirus. Investment in vaccine development in Canada will lead to vaccines against HIV and malaria [24].

\section{Vaccines in the United States}

The United States of America is the world leader in vaccine production, with two of the largest companies founded 1849 and 1891 by George Merck and Charles Pfizer.

The country's top vaccine manufacturers are Merck \& Co., Inc., which manufactures HPV, HepB, RV, varicella, and varicella-zoster vaccine; Sanofi Pharmaceuticals, which produces Haemophilus b, DTaP, influenza, rabies, IPV, MCV4, TD, and YF vaccines. Johnson \& Johnson manufactures experimental Ebola, HIV, RSV, and Zika vaccines. Pfizer produces pneumococcal and MCV4 vaccines $[25,26]$.

Licensing requests for medical products in the U.S grew substantially between the end of the 1990s and 2010, stimulated by the biotechnology industry's emergence [27]. In 2019, importations of pharmaceutical products and biological substances were USD 210.1 billion $(4.99 \%)$ of the total imported products. During the same year, the United States exported USD 59.6 billion (3.26\%) of pharmaceutical products. The Pharma industry represented the fastest growing sector among the top ten import and export categories [28].

The institution responsible for regulating vaccines in the US and most world countries is the FDA's Center for Biologics Evaluation and Research (CBER). They ensure that vaccines are safe and effective. The FDA also oversees the production of vaccines after the vaccine and its manufacturing process is approved. Vaccine clinical development follows the same general pathway as for drugs and other biologics [29].

This unique productive capacity and efficient local regulation, and the incentive for research and development make this country the undisputed leader in vaccines' world production. The local demands for vaccines are primarily satisfied with local production, and manufacturers allocate a large part of their production for export, creating a significant income for the national economy.

The United States of America recommended vaccines for children and adolescents are HepB, RV, DTaP, Hib, PCV, IPV, MMR, VAR, HepA, Tdap, HPV, MCV4, PVC, and influenza [30]. The US has a program to accelerate vaccines development with an annual budget of $\$ 1.00$ billion [18]. The most recent numbers stipulate that more than $90 \%$ of vaccination coverage is achieved in the country and come mostly from in-country local manufacturers.

In the general context of the COVID-19 pandemic, the US has put the lead on developing several candidates, including two RNA Vaccines, to tackle the effects of COVID-19 in the world. If any of the vaccines reaches the market, the revenue for their economy will be very significant.

\section{Vaccines in Mexico}

The production of vaccines in Mexico began in 1939. In 1970 the WHO recognized the National Institute of Virology as a regional reference center for vaccines. This governmental institution produces vaccines against rabies, MCV, tetanus, and poliomyelitis, covering 
approximately $90 \%$ of vaccines required from 1956 to 1960 [31].

In 1999, the Mexican government founded the firm General Biologic and Reactives from Mexico (BIRMEX). Each year Birmex imports control and distributes about 20 million doses of seasonal and pandemic influenza vaccine delivered to health institutions throughout the country [32]. The company is responsible for manufacturing 25 million OPV doses and 12 million DT doses, which covers the national demand. Birmex plants can produce up to 100 million vaccines a year, as well as two antidotes against the venom of Scorpion and vipers [31].

In 1998, when the measles, mumps, and rubella vaccine (MMR) was introduced, Mexico ceased to be selfsufficient in vaccines production [33]. Therefore, Mexico established a technology transfer agreement with Sanofi Pasteur to produce viral vaccines, like rabies, oral polio vaccine (OPV), and seasonal pandemic influenza vaccines. From 24 vaccines included in its EPI, Mexico ensures $25 \%$ of this demand [32].

Currently, the pharmaceutical industry in Mexico is the second largest industry in Latin America and ranks 12th worldwide. The total value of pharmaceutical products is 94 billion Mexican pesos, representing 1.2\% of the national gross domestic product [34], and the pharmaceutical sales for anti-infectives for systemic use during 2018 was USD 5.383 billion [18]. During the same year, Mexico imported USD 318 million of vaccines for human use. Meanwhile, exported USD 24.7 million of vaccines primarily to France [34] (Table 2).

\section{Vaccines in Cuba}

Over the years, Cuba has developed an interesting capacity to produce health technologies to maintain its national health system. Cuba is recognized for achieving vaccine universal vaccine coverage and other health indicators comparable with high-income countries in the Latin-American context. The biotech sector had its highest recognition in the 1980s, when Cuba had several qualified experts that were trained abroad. After the Soviet Union's fall, Cuban technological development declined, slowing national production of biotechnological products and biotechnological patents. In any case, this Caribbean country continues to produce research that has allowed it to position itself as the technology transfer leader to South American countries.

The Finlay Institute, the Center of Genetic Engineering and Biotechnology (CIGB), and the National Biopreparations Centre (BIOCEN) is one of the institutions that leads the production of vaccines. They have improved their technological capacities and produce combined vaccines based on DTwP, such as DTwP-HB and DTwP-HB-Hib, Meningococcal B outer membrane protein vaccines, $\mathrm{HepB}$, $\mathrm{HiB}$, leptospirosis vaccines,
Table 2 Imports and exports of vaccines for medical use in Mexico during 2018 [34]

\begin{tabular}{lll}
\hline Country & Imports & Exports \\
\hline France & USD 115 million & USD 24.6 million \\
United Kingdom & USD 56.9 million & No reported \\
India & USD 33.3 million & No reported \\
Ireland & USD 29.2 million & No reported \\
United States & USD 25.9 million & No reported \\
Belgium-Luxembourg & USD 21 million & No reported \\
Spain & USD 19.5 million & No reported \\
Canada & USD 8.37 million & No reported \\
Switzerland & USD 2.92 million & No reported \\
No reported Italy & USD 522 thousand & No reported \\
Germany No reported & USD 508 thousand & No reported \\
Chinese Taipei & USD 420 thousand & No reported \\
\hline
\end{tabular}

polysaccharide Vi Typhoid vaccines, and the meningococcal polysaccharide vaccine ACYW135. In Cuba, there are two vaccine producers: Center for Biotechnology and Bioengineering (CIGB) that produces HepB vaccine, Haemophilus influenzae type $\mathrm{b}$ vaccine, Tetravalent DPT-HB, Pentavalent DPT-HB-Hib and the Institute of Havana that produces Meningococcal $\mathrm{BC}$ vaccine, Trivalent leptospirosis vaccine $\mathrm{Vi}$, polysaccharide typhoid vaccine Tetanus vaccine, DT vaccine, DTwP vaccine [32].

In this sense, Cuba has become self-sufficient in terms of vaccine production in the region, covering more than $72.7 \%$ of its national needs with local production.

In recent years, Bio-Manguinhos Institute from Brazil and Cuba have established a cooperation agreement with the Finlay Institute to produce a meningococcal polysaccharide $\mathrm{A} / \mathrm{C}$ vaccine to eradicate meningitis in Africa. This benefits both countries, including the construction of a good manufacturing procedures (GMP) facility in Cuba for meningococcal polysaccharide production, introducing this vaccine in the Brazilian EPI, WHO prequalification of the product in 2007, and collaborative interaction of their national regulatory agencies [32].

According to data from the national pharmaceutical bureau, the Cuban pharmaceutical industry generated more than 2.7 billion dollars in pharmaceutical products from 2008 to 2013, a remarkable amount considering that Cuban products are exported to many countries in the world [31-33].

\section{Vaccines in Honduras}

Honduras does not produce vaccines for human use. The internal consumption is based on importations and resources that are not produced within the country. The country's public health needs are part of the EPI program supported by the Panamerican Health Organization (PAHO). The private needs are based on imports by 
private pharmaceutical companies such as Farsiman, Henie Farma, Kernel, MC Pharmaceutics Corporation, Finlay, Infarma, aiming to prevent infectious diseases that are prevalent such as pneumococcal pneumonia, rotavirus, measles, or mumps [35].

According to latest data, in 2018, Honduras imported vaccines for human use primarily from South Korea (32\%), Belgium- Luxembourg (26.8\%), India (17.6\%), Netherlands (13,3\%), Switzerland (4,91\%), United States (2.1\%), France $(2.08 \%)$, Indonesia $(0.76 \%)$, Canada (0.27\%), and the U.K (0.09\%) [36].

The overall supply of vaccines has contributed to achieved vaccination coverages that are close to $95 \%$ in some cases, putting Honduras ahead of other countries in terms of coverage and was recognized by PAHO and WHO for achieving 97\% coverage [37]. The primary health services' mandatory scheme are BCG, Pediatric HepB, OPV, RV, pentavalent (DPT-Hep B- Hib, pneumococcal 13 valent, MRM, RM, DTP, DT, HPV, adult Hepatitis, HepA, influenza, and YF [37].

.Lastly, for some highly needed vaccines and were not available locally, such as the 13-valent pneumococcal vaccine, the government created a joint effort with the Gavi Alliance, PAHO, and UNICEF to supply the amount required by vaccination programs [38].

\section{Vaccines in Nicaragua}

Nicaragua has not produced vaccines; nevertheless, it has near-future plans to build a vaccine production plant that would supply the country and certain countries in the region.

The cooperation among Russia and Nicaragua will result in the construction of a laboratory and manufacturer plant in Managua (ElieMéchnikov), produce vaccines against epidemics, and supply the rest of the Central American countries and the countries of the Bolivarian Alliance for the Peoples of America (ALBA). The research objectives of ElieMéchnikov are the production of vaccines for diseases as dengue, chikungunya, yellow fever, and influenza. It is expected to manufacture at least 30 million flu vaccines per year [39]. ElieMéchnikov laboratory represents an investment of 21 million dollars, of which 7 million were assumed by Nicaragua and Russia assumed 14 million. The laboratory is equipped with technology from the San Petersburg Vaccine and Serum Institute.

According to the Observatory of Economic Complexity (OEC), during 2018, Nicaragua imported USD 9.02 million of human use vaccines, mainly from BelgiumLuxembourg (USD 3.72 million), India (2.17million), France (USD 717 thousand), Russia (USD 602 thousand), The Netherlands (USD 584 thousand), and Turkey (USD 495 thousand) [36]. The Gavi Alliance's economic contribution to Nicaragua's Government from 2000 to 2019 is described in Table 3.

\section{Vaccines in Panama}

Panama has one of the best vaccination schemes in the Region of the Americas [41]. Since the creation of the Expanded Immunization Program in 1978, the country has focused its actions on keeping the country free of preventable diseases, making vaccination freely accessible to all citizens [42]. The country's mandatory vaccines are YF, DT / DTw, MMR, HepA, and HepB vaccines [43]. The leading pharmaceutical supplier is Sanofi [32]. Nonetheless, in 2010 Panama exported large quantities of $\mathrm{H} 1 \mathrm{~N} 1$ vaccines to Chile and the Central America region [43].

During 2018, Panama imported USD 30.4 million of vaccines for human use, mainly from BelgiumLuxembourg (USD 11.1 million), United States (USD 8.22 million), United Kingdom (USD 3.44 million), France (USD 3.1 million), and Canada (USD 2 million). Meanwhile, exported USD 825 thousand to Costa Rica (USD 634 thousand), Guyana (USD 125 thousand), Ghana (USD 58.7 thousand), and Suriname (USD 5.9 Thousand) [36].

Table 3 Economic contribution to Nicaragua. Source: Gavi's Report [40]

\begin{tabular}{lll}
\hline Type of support & Approvals & $\begin{array}{c}\text { Disbursements } \\
\text { 2000-2019 (USD) }\end{array}$ \\
\hline Health system strengthening (HSS 2) & $\mathbf{2 0 0 1 - 2 0 2 3}$ (USD) & $\$ 3,793,600$ \\
Immunization services support (ISS) & $\$ 3,793,600$ & $\$ 293,280$ \\
Injection Safety Devices (NVS) & $\$ 293,280$ & $\$ 74,000$ \\
Injection safety support (INS) & $\$ 74,000$ & $\$ 461,990$ \\
Vaccine against Polio & $\$ 461,990$ & $\$ 2,040,500$ \\
Pneumo (NVS) & $\$ 2,040,500$ & $\$ 17,915,772$ \\
Rotavirus (NVS) & $\$ 16,361,767$ & $\$ 12,729,500$ \\
Vaccine Introduction Grant (VIG) & $\$ 14,024,262$ & $\$ 309,935$ \\
TOTAL & $\$ 309,935$ & $\$ 37,618,577$ \\
\hline
\end{tabular}




\section{Vaccines in Colombia}

The National Institute of Health in Colombia has an internal capacity to produce BCG vaccine and has improved its laboratories to manufacture a YF vaccine for the international market. Colombia provides $7 \%$ of its national immunization needs [32]. In November 2016, a vaccine against malaria was announced, the "Colombian Falciparum Vaccine" (Colfavac). This vaccine was developed by the Foundation Institute of Immunology of Colombia (FIDIC) after 35 years of research [44]. Colfavac is currently ready to be tested in humans after succeeding in pre-clinical trials.

Leading pharmaceutical suppliers of vaccines in Colombia are Biotoscana, Manufacturing Process Prom, Vesalius Pharma, and Sanofi Pasteur. While the primary pharmaceutical producers of vaccines in Colombia are FIDIC, SGS -Vaccines and Biological Products, and Sanofi-Colombia [15].

During 2018, Colombia imported USD 106 million of vaccines for human use, mainly from BelgiumLuxembourg (43.6\%), the US (17.5\%), France (16.2\%), India (8.52\%), and South Korea (5.47\%) [36].

\section{Vaccines in Venezuela}

In close cooperation with Cuba, Venezuela launched in 2014 a project to build a vaccine production plant. This plant will favor developing local capacities to prepare vaccines against emerging and re-emerging diseases such as tetanus and diphtheria. Since their initial installation, the National Institute of Hygiene Rafael Rangel produces DTwP and rabies vaccine components in their recently built facility.

Although the country's political and economic deterioration has exacerbated poverty, it appears to be still in operation, administering some locally produced vaccines to the national vaccination scheme. The plant includes large-scale fermentation and purification processes for DTwP antigens equipment, and a facility for the formulation, filling, and packaging of 35 million vaccine doses. According to the information available, the plant can produce 50 million doses once it reaches $100 \%$ of its manufacturing capacity.

Although Venezuela imported more than USD 14.2 million of vaccines for human use from India (USD 12.8 million), France (USD 1.27 million), and Denmark (USD 165 thousand) in 2014, the vaccine coverage rates are inconsistent with the official information available [36].

It seems like Venezuela appears to be able to produce DT locally and $\mathrm{wP}$ antigens to formulate a pentavalent DTwP-HB-Hib vaccine using a technology transfer model similar to the Cuban System [32]. Although no information regarding safety and efficacy is available, Venezuela reported that a locally produced $\mathrm{H} 1 \mathrm{~N} 1$ vaccine was used for national vaccination programs [45].

\section{Vaccines in Peru}

Like most Latin American countries, Peru has a limited biotechnology industry and very scarce production of vaccines for human use. In general terms, the Andean country allocates most of its resources to importing vaccines and the local production of a few vaccines for animal use.

In the past, Peru joined the EPI strategy in 1984 with low levels of coverage that did not exceed $20 \%$. Nevertheless, 10 years later, the Andean country achieved an impressive $80 \%$ vaccine coverage rate $[45,46]$. In 1994, Peru received significant international support to eradicate poliomyelitis and reduced the presence of other infectious diseases that were highly prevalent such as measles and rubella [47]. However, a regression in the country's immunization efforts fails to reach the minimum standards [48]. Peru is one of the countries within the region, with relatively small production capacities and minimum potential for developing new technologies [32]. However, the Peruvian state funds $100 \%$ of the national vaccines program $[45,46]$.

UNICEF since 1982 has collaborated with the Peruvian immunization program, investing USD 2,200,000 for vaccine acquisition in a campaign against measles and rubella. Additionally, in March 2015, Peru and France launched a cooperative technology transfer project with SANOFI-Pasteur laboratory for vaccine manufacturing $[49,50]$. This project's goals are smallpox, Meas, OPV, rubella, avian influenza, among other viruses and vaccines [49].

During 2018, Peru imported vaccines for human use mainly from Belgium - Luxembourg (USD 27.6 million), United States (USD 16.3 million), France (USD 14.5 million), India (USD 10.6 million), and South Korea (USD 9.76 million), meanwhile exported all its production to Singapore (USD 8.6 thousand) [36].

\section{Vaccines in Brazil}

Brazil is the major vaccine manufacturer in the region. The country is self-sufficient for $54 \%$ of vaccination needs, including DTP, DT for adults and infants, TT, HepB, and DTP combined vaccines (DTP-HB and DTPHB-Hib), seasonal influenza vaccine, YF vaccine, and meningo $\mathrm{ApC}$ based on a cooperation agreement between Biomanguinhos and Finlay Institute from Cuba. Other vaccines as MMR, OPV, pneumococcal, and RV vaccines are manufactured due to partnerships and technology transfer agreements with European pharmaceuticals as GlaxoSmithKline (GSK). Butantan Institute is developing other vaccines, such as rabies, RV, and influenza, which will increase regional capacity. In addition, decavalent pneumococcal conjugated vaccine, dengue, and acellular pertussis vaccines are in the scale-up phase, with clinical trials in development [32]. 
The three leading vaccine producers in Brazil are Butantan Institute San Paolo that elevates DTwP, DT, rabies HB., seasonal, and pandemic influenza vaccine. Fiocruz/Biomanguinhos that produces Tetravalent DPTHib, Meningitides A and $\mathrm{C}$ polysaccharide, Hib, PCV, YF, OPV, MMR, and RV vaccine; and Technological Institute of Parana was involved in rabies and bacterial vaccine production [32].

The country ensured its vaccine production in Biomanguinhos and Butantan Institute by investing in facilities for the formulation, filling, lyophilizing, final processing, and a technological platform for viral vaccines. In the past, other public laboratories, such as the Institute of Technology of Paraná (TECPAR), were developing bacterial and viral vaccines, but investments in facilities were needed to fulfill GMP [32].

Brazil's vaccine production is focused on both supplying national needs and for exportation. Vaccines such as for measles and rubella are manufactured for the Bill and Melinda Gates Foundation. This foundation has donated some of these vaccines to developing countries unable to afford them in Africa. Brazil exports mainly triple viral SRP vaccines because these are the most common in the country [51].

Brazil is one of the major worldwide producers of the YF vaccine, with the lowest market price. During 2017 and 2018, Brazil refrained from exporting the vaccine due to the reduction of production. The domestic demand increased significantly due to the need to face an outbreak [52]. The Foundation Oswaldo Cruz, the official vaccine's producer of the Brazilian Health Ministry, announced to PAHO and UNICEF that from 2019 to 2020 , they supply both organizations with 23 million vaccines. WHO certifies these vaccines since 2011 [52].

Human use vaccines in Brazil are imported mainly from Belgium- Luxemburg (USD 273 million), Italy (USD 91.5 million), France (USD 89.9 million), United States (USD44 million), and India (USD 43.2 million). In contrast, the major export destinations are France, Argentina, Colombia, Angola, Chile, and Ecuador [53].

\section{Vaccines in Bolivia}

In 1826, the Medical Institute Sucre (IMS) developed the smallpox vaccine [54]. In 1979, the Bolivarian Government implemented the national immunization program eradicating diseases like poliomyelitis, measles, and rubella. Bolivia imports vaccines mainly from the United States, Belgium- Luxembourg, France, India, and South Korea $[38,52]$. Bolivia has acquired vaccines through donations, as well. The national immunization scheme has 11 mandatory vaccines for 17 diseases, including BCG, OPV, Pneumococcal, RV, seasonal antipyretic pediatric, MMR, and DTP vaccines [54].
Bolivia imported all vaccines for national use. During 2018, Bolivia imported USD 17.1 million in vaccines for human use manly from Belgium-Luxembourg (USD 4.62 million), India (USD 3.99 million), South Korea (USD 2.56 million), United States (USD 2.31 million), and France (USD 2.15 million) [36].

\section{Vaccines in Paraguay}

In 2011, Paraguay's expenses in health and concerning pharmaceuticals were \$ 2.985 billion [55]. During 2013 there were 22 pharmaceutical manufacturers in Paraguay, such as LASCA, SA, and Catedral Laboratories SA. There is no robust data about the national production of vaccines. EPI provides free vaccines to children under five, pregnant women, the elderly, and poor people [56].

During 2018, Paraguay exported a total of USD 36.4 thousand in vaccine for human use entirely to Argentina, while it imported USD 12.1 million from the United States (37\%), France (22.6\%), Belgium-Luxembourg (13\%), Canada (9.61\%), and India (6.22\%) [36].

\section{Vaccines in Argentina}

In Argentina, three different public institutions are involved in the production of vaccines. The Malbrán Institute produces DTP and BCG vaccines in limited quantities not under of GMP. Current goals of production are focused on antiserum for different diseases. The Institute will invest in facilities to manufacture DTwP and combined vaccines based on DTwP. On the other hand, the Institute of Human Viral Diseases Julio Maiztegui built a plant production for vaccines against Argentine hemorrhagic fever that may produce other antiviral vaccines [32, 57]. The live attenuated anti-Argentine hemorrhagic fever vaccine was developed through a joint international effort that envisioned it as an orphan drug [32, 58]. The FDA has not yet approved this vaccine, and it is in the testing phase for approval [59].

Sinergium Biotech is an argentine industry under a technological alliances model, and technological transfer projects develop modern vaccines against influenza, HPV, and pneumococcus. The biotechnological firm started a public-private partnership to expand access to health, supplying vaccines, many of them free-provided, as they integrate the official vaccination schedule [37]. This laboratory is getting ready to distribute 12 million doses of vaccines, with a capacity to supply South America. It is capable of manufacturing the vaccine of zika virus as soon as it is tested and certified. Vaccines are accredited by the National Administration of Medicine, Food and Medical Technology (ANMAT), whose certification is recognized by all South American countries except Brazil [37]. 
In 2016, an agreement was announced between the company Sinergium Biotech (an Argentine biotechnology company that develops, manufactures, and markets different vaccines, including the flu, for pneumococcus and HPV), the Mundo Sano Foundation, and the North American company Protein Sciences for the development in Argentina of a vaccine against Zika [60].

The vaccine to be developed will be based on the production of recombinant variants of the Zika virus protein E. Other similar vaccines in development produced by Protein Sciences against West Nile virus and Japanese encephalitis, both related to Zika, have demonstrated their ability to neutralize their respective viruses in preclinical studies [61].

Argentina imported human vaccines mainly from Italy (USD 47 million), United States (USD 37.4 million), Belgium- Luxemburg (USD 30.7 million), Ireland (USD 20.2 million), and France (USD15.7 million). While the major export destinations are India (USD 818 thousand), Pakistan (USD 534 thousand), Paraguay (USD 317 thousand), and Bolivia (USD 128 thousand) [53].

In Argentina, the National Administration of Laboratories and Institute of Health (ANLIS) "Dr. Carlos G. Malbrán." Institute of Human Viral Disease" Julio Maistegui" produces vaccines as Virus Junin live attenuated vaccine against Argentine Hemorrhagic Fever Rabies vaccine (Table 4) [32].

\section{Vaccines in Uruguay}

Uruguay is one of the leading cattle producers of South America; consequently, they have developed research and vaccine manufacturing for cattle, which could be a basis for human vaccine production. The Pasteur Institute of Montevideo and the Clausen Laboratory work together with the Ministry of Public Health for the national production of vaccines [67].

Vaccines are produced to combat seasonal influenza. Authorities recognized that the H1N1 vaccine's approval could open lines of research involving biochemists, biologists, chemical engineers, and all professionals working in the production of vaccines and the prevention of diseases [68]. This initiative fulfills one of the objectives of the Pasteur Institute in Montevideo. On the other hand, the Clausen Laboratory installed in Uruguay already works with biological products [67]. This small country in South America exports high value-added goods to other countries in the region, including animal vaccines and very sporadic, human-designed biological products (Table 5).

Uruguay imports human vaccines mainly from the United States (USD 2.46 million), France (USD 2.22 million), Netherlands (USD 2.19 million), South Korea (USD 1.66 million), and Belgium- Luxembourg (USD 1.32 million). At the same time, the major export destinations are Guyana (USD 31.2 thousand), Pakistan (USD 13.7 thousand), and India (USD 3.04 thousand) [53].

\section{Vaccines in Ecuador}

This South American country achieved some historical milestones of biotechnological development, especially with the contributions of the development of vaccines

Table 4 Novel vaccines produced in Argentina

\begin{tabular}{|c|c|c|}
\hline Institute that provides/ developed & Disease & Description \\
\hline CONICET, CIDE & Giardiasis & $\begin{array}{l}\text { An oral vaccine against giardiasis. } \\
\text { According to the WHO, this disease infects } 200 \text { million people in } \\
\text { Africa, Asia, and Latin America, with a particular impact on children up } \\
\text { to } 5 \text { years because they are in a development stage where proper } \\
\text { nutrition is vital. } \\
\text { The purpose of the vaccine is to fight this intestinal parasite, which } \\
\text { can lead to eating disorders, severe inadequate absorption syndromes, } \\
\text { and whose most severe forms are malnutrition, dehydration, and } \\
\text { diarrhea, which in some cases can cause death [62]. }\end{array}$ \\
\hline IIBBA COMICET, Instituto Leloir & HPV & $\begin{array}{l}\text { A pre-clinical staged technology to produce a vaccine against HPV. } \\
\text { The technology developed by the researchers consists of assembling } \\
\text { a virus identical to the pathogen but "empty." } \\
\text { To create this pseudovirus that activates the system's immune } \\
\text { response, the virus's capsid is isolated }[63,64] \text {. }\end{array}$ \\
\hline $\begin{array}{l}\text { The Institute for the Study of humoral immunity (IDEHU) and } \\
\text { the Institute for Research in medical microbiology and } \\
\text { parasitology (IMPAM) }\end{array}$ & $\begin{array}{l}\text { Chagas } \\
\text { Disease }\end{array}$ & $\begin{array}{l}\text { Experimental vaccines with preliminary results are promising. } \\
\text { The finding refers to studying the effects of a designed molecule that } \\
\text { combines the essential immunogenic characteristics of three parasites } \\
\text { antigens that causes the disease }[65] \text {. }\end{array}$ \\
\hline Sinergium Biotech & Zika fever & $\begin{array}{l}\text { The vaccine is made up of a purified protein called "protein E" that } \\
\text { matches a protein naturally found on the surface of the Zika virus. } \\
\text { According to early results from pre-clinical studies with mice, the puri } \\
\text { fied protein formulated in the laboratory elicits strong levels of neutral } \\
\text { izing antibodies, which is a positive indicator that the vaccine will } \\
\text { protect against Zika virus infection [66]. }\end{array}$ \\
\hline
\end{tabular}


Table 5 Exportations of the Uruguayan Pharma sector [61]

\begin{tabular}{ll}
\hline Product description & Part (\%) \\
\hline Medications conditioned for retail sale & $59 \%$ \\
Vaccines and antiserum & $26 \%$ \\
Pharmaceutical preparations and devices & $8 \%$ \\
Provitamins and vitamins natural or reproduced by synthesis & $3 \%$ \\
Natural or reproduced hormones by synthesis & $3 \%$ \\
Other & $1 \%$ \\
\hline
\end{tabular}

and toxoids such as BCG and the Tetanus vaccine. Ecuador was one of the first countries to produce vaccines in the region. In 1938 the first clinical trials for the BCG vaccine production were carried out, and the vaccine was distributed soon after $[69,70]$. Since that beginning, the country has been progressively producing more vaccines, including toxoids and antivenom for human use (Table 6).

After producing vaccines for many years, the only local plant that produced biologicals was forced to close due to the lack of political will and monetary resources [70]. Currently, Ecuador has 18 specific vaccines within the national scheme to prevent infectious diseases, including chickenpox, rubella, pneumococci, HPV, and influenza; nevertheless, all of them are now imported $[69,71]$.
The latest numbers suggest that Ecuador imports human vaccines mainly from Belgium- Luxembourg (USD 17.5 million), South Korea (USD 10.9 million), India (USD 3.74 million), Russia (USD 3.68 million), France (USD 3.68 million), and France (USD 2.36 million). While the only export destination registered is Panamá [53].

Ecuador is currently facing a reduction in its vaccination coverages according to the Pan-American Health Organization (PAHO) [72]. This reduction might be linked to the disappearance of the local production capabilities, jeopardizing children's coverages and increasing the risk of future outbreaks.

Vaccines in other countries from south or Central America Vaccine production in other smaller countries in the Caribbean, Central or South America is limited. Countries like French Guiana, El Salvador, or Belize have extremely small markets, and the production of biological medicines is not profitable for the target population. Countries like Costa Rica or Puerto Rico have an important and growing pharmaceutical industry; however, the technology to produce their own vaccine is not implemented at a big scale level. Their market's needs are entirely turned over to the

Table 6 Amounts necessary for the acquisition of vaccines by the PAI in Ecuador and percentage of Imports of vaccines in relation to local production, Source PAl, prepared by the Author [70]

\begin{tabular}{|c|c|c|c|c|}
\hline Vaccine name & Revolving fund via EPI & Enfarma / Inspi & \% of imports 2013 & \% Imports 2016 \\
\hline BCG & $\$ 89.647$ & & $100 \%$ & $100 \%$ \\
\hline MMR & $\$ 852.194$ & & $100 \%$ & $100 \%$ \\
\hline MR & $\$ 105.344$ & & $100 \%$ & $100 \%$ \\
\hline Polio Vaccine & $\$ 402.780$ & & $100 \%$ & $100 \%$ \\
\hline Rotavirus Vaccine & $\$ 4.011 .333$ & & $100 \%$ & $100 \%$ \\
\hline Pneumococcal vaccine & $\$ 819.275$ & & $100 \%$ & $100 \%$ \\
\hline Immunoglobulin HB. & $\$ 8.807$ & & $100 \%$ & $100 \%$ \\
\hline Chickenpox vaccine & $\$ 5.129 .735$ & & $100 \%$ & $100 \%$ \\
\hline Yellow fever vaccine & $\$ 1.585 .111$ & & $100 \%$ & $100 \%$ \\
\hline Influenza & $\$ 6.644 .748$ & & $100 \%$ & $100 \%$ \\
\hline Trivalent influenza & $\$ 3.743 .625$ & & $100 \%$ & $100 \%$ \\
\hline Pediatric trivalent influenza & $\$ 1.032 .000$ & & $100 \%$ & $100 \%$ \\
\hline Conjugated Pneumococcal vaccine & $\$ 15.272 .250$ & & $100 \%$ & $100 \%$ \\
\hline DT adults & & $\$ 247.200$ & $39 \%$ & $100 \%$ \\
\hline Anti-meningococcal & & $\$ 29.960$ & $100 \%$ & $100 \%$ \\
\hline Hep B & & $\$ 292.500$ & $100 \%$ & $100 \%$ \\
\hline Pediatric Hep B & & $\$ 25.500$ & $100 \%$ & $100 \%$ \\
\hline Pentavalent & & $\$ 3.431 .000$ & $100 \%$ & $100 \%$ \\
\hline DPT & & $\$ 92.000$ & $0 \%$ & $100 \%$ \\
\hline DT Pediatric & & $\$ 72.000$ & $0 \%$ & $100 \%$ \\
\hline Total & $\$ 39.696 .850$ & $\$ 4.190 .160$ & $88 \%$ & $100 \%$ \\
\hline
\end{tabular}


Table 7 List of countries in the Americas and their vaccine production capabilities as well as their share in the exportation market

\begin{tabular}{|c|c|c|c|c|c|c|}
\hline \multirow{2}{*}{$\begin{array}{l}\text { Country } \\
\text { Antigua and } \\
\text { Barbuda }\end{array}$} & \multirow{2}{*}{$\begin{array}{l}\text { Number of vaccines } \\
\text { introduced in the EPI } \\
\text { [74] } \\
16\end{array}$} & \multirow{2}{*}{$\begin{array}{l}\text { Vaccine produced } \\
\text { in own facility } \\
0\end{array}$} & \multirow{2}{*}{$\begin{array}{l}\text { Local vaccine } \\
\text { production }^{\mathrm{a}}(\%)\end{array}$} & \multirow{2}{*}{$\begin{array}{l}\text { Ranking in world exports of } \\
\text { vaccines for human use [75] } \\
\text { No information reported }\end{array}$} & \multicolumn{2}{|c|}{$\begin{array}{l}{ }^{\text {b}} \text { Vaccine } \\
\text { Type and } \\
\text { target } \\
\text { achieved } \\
{[76]}\end{array}$} \\
\hline & & & & & $\begin{array}{l}\text { HepB3 } \\
\text { Hib3 } \\
\text { IPV } \\
\text { Pol3 } \\
\text { DTP3 } \\
\text { MCV2 } \\
\text { MCV1 } \\
\text { RCV1 }\end{array}$ & $\begin{array}{l}99 \% \\
99 \% \\
99 \% \\
95 \% \\
95 \% \\
95 \% \\
93 \% \\
93 \%\end{array}$ \\
\hline Argentina & 26 & 9 & 34.62 & 49 & $\begin{array}{l}\text { MCV1 } \\
\text { RCV1 } \\
\text { BCG } \\
\text { IPV } \\
\text { MCV2 } \\
\text { PCV3 } \\
\text { HepB3 } \\
\text { Hib3 } \\
\text { DTP3 } \\
\text { Pol3 } \\
\text { RV } \\
\text { YFV }\end{array}$ & $\begin{array}{l}94 \% \\
94 \% \\
93 \% \\
90 \% \\
89 \% \\
88 \% \\
86 \% \\
86 \% \\
86 \% \\
84 \% \\
72 \% \\
8 \%\end{array}$ \\
\hline Bahamas & 22 & 0 & 0 & No information reported & $\begin{array}{l}\text { IPV } \\
\text { Hep3 } \\
\text { Hib3 } \\
\text { PCV3 } \\
\text { Pol3 } \\
\text { DTP3 } \\
\text { MCV1 } \\
\text { RCV1 } \\
\text { MCV2 } \\
\text { RV }\end{array}$ & $\begin{array}{l}91 \% \\
86 \% \\
86 \% \\
86 \% \\
86 \% \\
86 \% \\
86 \% \\
85 \% \\
82 \% \\
78 \%\end{array}$ \\
\hline Barbados & 15 & 0 & 0 & 63 & $\begin{array}{l}\text { IPV } \\
\text { PCV3 } \\
\text { MCV1 } \\
\text { RCV1 } \\
\text { Pol3 } \\
\text { HepB3 } \\
\text { Hib3 } \\
\text { DTP3 } \\
\text { MCV }\end{array}$ & $\begin{array}{l}94 \% \\
93 \% \\
92 \% \\
92 \% \\
91 \% \\
90 \% \\
90 \% \\
90 \% \\
77 \%\end{array}$ \\
\hline Belize & 16 & 0 & 0 & No information reported & $\begin{array}{l}\text { IPV } \\
\text { Hib3 } \\
\text { Pol3 } \\
\text { DTP3 } \\
\text { MCV1 } \\
\text { RCV1 } \\
\text { BCG } \\
\text { MCV2 } \\
\text { HepB3 }\end{array}$ & $\begin{array}{l}99 \% \\
98 \% \\
98 \% \\
98 \% \\
96 \% \\
96 \% \\
95 \% \\
95 \% \\
98 \%\end{array}$ \\
\hline Bolivia & 14 & 1 & 7.14 & No information reported & $\begin{array}{l}\text { IPV } \\
\text { BCG } \\
\text { MCV1 } \\
\text { RCV1 } \\
\text { RV } \\
\text { YFV } \\
\text { HepB3 } \\
\text { Hib3 } \\
\text { PCV3 } \\
\text { Pol3 } \\
\text { DTP } \\
\text { MCV2 }\end{array}$ & $\begin{array}{l}81 \% \\
80 \% \\
79 \% \\
78 \% \\
77 \% \\
75 \% \\
75 \% \\
75 \% \\
75 \% \\
75 \% \\
75 \% \\
44 \%\end{array}$ \\
\hline
\end{tabular}


Table 7 List of countries in the Americas and their vaccine production capabilities as well as their share in the exportation market (Continued)

\begin{tabular}{|c|c|c|c|c|c|c|}
\hline \multirow{2}{*}{$\begin{array}{l}\text { Country } \\
\text { Brazil }\end{array}$} & \multirow{2}{*}{$\begin{array}{l}\text { Number of vaccines } \\
\text { introduced in the EPI } \\
\text { [74] } \\
27\end{array}$} & \multirow{2}{*}{$\begin{array}{l}\text { Vaccine produced } \\
\text { in own facility } \\
13\end{array}$} & \multirow{2}{*}{$\begin{array}{l}\text { Local vaccine } \\
\text { production }^{\mathrm{a}}(\%)\end{array}$} & \multirow{2}{*}{$\begin{array}{l}\text { Ranking in world exports of } \\
\text { vaccines for human use [75] } \\
32\end{array}$} & \multicolumn{2}{|c|}{$\begin{array}{l}{ }^{b} \text { Vaccine } \\
\text { Type and } \\
\text { target } \\
\text { achieved } \\
{[76]}\end{array}$} \\
\hline & & & & & $\begin{array}{l}\text { MCV1 } \\
\text { RCV1 } \\
\text { IPV } \\
\text { Poli3 } \\
\text { PCV3 } \\
\text { RV } \\
\text { HepB3 } \\
\text { Hib3 } \\
\text { BCG } \\
\text { DTP3 } \\
\text { YFV } \\
\text { MCV2 }\end{array}$ & $\begin{array}{l}91 \% \\
91 \% \\
86 \% \\
85 \% \\
84 \% \\
83 \% \\
80 \% \\
80 \% \\
79 \% \\
73 \% \\
60 \% \\
54 \%\end{array}$ \\
\hline Canada & 21 & 5 & 23.81 & 11 & $\begin{array}{l}\text { IPV } \\
\text { Hib3 } \\
\text { Pol3 } \\
\text { DTP3 } \\
\text { MCV1 } \\
\text { RCV1 } \\
\text { MCV2 } \\
\text { PCV3 } \\
\text { RV } \\
\text { HepB3 }\end{array}$ & $\begin{array}{l}94 \% \\
91 \% \\
91 \% \\
91 \% \\
90 \% \\
90 \% \\
87 \% \\
81 \% \\
79 \% \\
74 \%\end{array}$ \\
\hline Chile & 19 & 0 & 0 & No information reported & $\begin{array}{l}\text { IPV } \\
\text { BCG } \\
\text { HepB3 } \\
\text { Hib3 } \\
\text { Pol3 } \\
\text { DTP3 } \\
\text { MCV1 } \\
\text { PCV3 } \\
\text { RCV1 } \\
\text { MCV2 }\end{array}$ & $\begin{array}{l}99 \% \\
98 \% \\
96 \% \\
96 \% \\
96 \% \\
96 \% \\
95 \% \\
95 \% \\
95 \% \\
91 \%\end{array}$ \\
\hline Colombia & 22 & 3 & 13.64 & 54 & $\begin{array}{l}\text { MCV1 } \\
\text { RCV1 } \\
\text { PCV3 } \\
\text { IPV } \\
\text { HepB3 } \\
\text { Hib3 } \\
\text { Pol3 } \\
\text { DTP3 } \\
\text { RV } \\
\text { BCG } \\
\text { MCV2 } \\
\text { YFV }\end{array}$ & $\begin{array}{l}95 \% \\
95 \% \\
94 \% \\
93 \% \\
92 \% \\
92 \% \\
92 \% \\
92 \% \\
90 \% \\
89 \% \\
88 \% \\
87 \%\end{array}$ \\
\hline Costa Rica & 15 & 0 & 0 & 74 & $\begin{array}{l}\text { HepB3 } \\
\text { IPV } \\
\text { MCV1 } \\
\text { PCV3 } \\
\text { RCV1 } \\
\text { DTP3 } \\
\text { Hib3 } \\
\text { Pol3 } \\
\text { MCV2 } \\
\text { BCG } \\
\text { RV }\end{array}$ & $\begin{array}{l}98 \% \\
96 \% \\
95 \% \\
95 \% \\
95 \% \\
95 \% \\
94 \% \\
94 \% \\
93 \% \\
88 \% \\
59 \%\end{array}$ \\
\hline Cuba & 16 & 9 & $56.25 \%$ & 43 & $\begin{array}{l}\text { BCG } \\
\text { HepB3 } \\
\text { Hib3 } \\
\text { IPV } \\
\text { MCV1 }\end{array}$ & $\begin{array}{l}99 \% \\
99 \% \\
99 \% \\
99 \% \\
99 \%\end{array}$ \\
\hline
\end{tabular}


Table 7 List of countries in the Americas and their vaccine production capabilities as well as their share in the exportation market (Continued)

\begin{tabular}{|c|c|c|c|c|c|c|}
\hline \multirow[t]{2}{*}{ Country } & \multirow[t]{2}{*}{$\begin{array}{l}\text { Number of vaccines } \\
\text { introduced in the EPI } \\
\text { [74] }\end{array}$} & \multirow[t]{2}{*}{$\begin{array}{l}\text { Vaccine produced } \\
\text { in own facility }\end{array}$} & \multirow[t]{2}{*}{$\begin{array}{l}\text { Local vaccine } \\
\text { production }^{\mathrm{a}}(\%)\end{array}$} & \multirow[t]{2}{*}{$\begin{array}{l}\text { Ranking in world exports of } \\
\text { vaccines for human use [75] }\end{array}$} & \multicolumn{2}{|c|}{$\begin{array}{l}{ }^{\mathrm{b}} \text { Vaccine } \\
\text { Type and } \\
\text { target } \\
\text { achieved } \\
{[76]}\end{array}$} \\
\hline & & & & & $\begin{array}{l}\text { Pol3 } \\
\text { RCV1 } \\
\text { DTP3 } \\
\text { MCV2 }\end{array}$ & $\begin{array}{l}99 \% \\
99 \% \\
99 \% \\
99 \%\end{array}$ \\
\hline Dominica & 14 & 0 & 0 & No information reported & $\begin{array}{l}\text { HepB3 } \\
\text { Hib3 } \\
\text { IPV } \\
\text { Pol3 } \\
\text { DTP } \\
\text { BCG } \\
\text { MCV1 } \\
\text { RCV1 } \\
\text { MCV2 }\end{array}$ & $\begin{array}{l}99 \% \\
99 \% \\
99 \% \\
99 \% \\
99 \% \\
98 \% \\
92 \% \\
92 \% \\
92 \%\end{array}$ \\
\hline Dominican Republic & 18 & 0 & 0 & No information reported & $\begin{array}{l}\text { BCG } \\
\text { IPV } \\
\text { MCV1 } \\
\text { RCV1 } \\
\text { Pol3 } \\
\text { DTP3 } \\
\text { HepB3 } \\
\text { RV } \\
\text { Hib3 } \\
\text { PCV3 } \\
\text { MCV2 }\end{array}$ & $\begin{array}{l}99 \% \\
98 \% \\
96 \% \\
96 \% \\
92 \% \\
89 \% \\
87 \% \\
80 \% \\
79 \% \\
70 \% \\
60 \%\end{array}$ \\
\hline Ecuador & 18 & 2 & 11.1 & No information reported & $\begin{array}{l}\text { BCG } \\
\text { HepB3 } \\
\text { Hib3 } \\
\text { IPV } \\
\text { Pol3 } \\
\text { RV } \\
\text { DTP3 } \\
\text { YFV } \\
\text { MCV1 } \\
\text { PCV3 } \\
\text { RCV1 } \\
\text { MCV2 }\end{array}$ & $\begin{array}{l}86 \% \\
85 \% \\
85 \% \\
85 \% \\
85 \% \\
85 \% \\
85 \% \\
84 \% \\
83 \% \\
83 \% \\
83 \% \\
76 \%\end{array}$ \\
\hline El Salvador & 19 & 0 & 0 & No information reported & $\begin{array}{l}\text { IPV } \\
\text { Hib3 } \\
\text { Pol3 } \\
\text { DTP3 } \\
\text { MCV1 } \\
\text { RCV1 } \\
\text { MCV2 } \\
\text { BCG } \\
\text { HepB3 } \\
\text { PCV3 } \\
\text { RV }\end{array}$ & $\begin{array}{l}81 \% \\
81 \% \\
81 \% \\
81 \% \\
82 \% \\
82 \% \\
87 \% \\
78 \% \\
81 \% \\
82 \% \\
82 \%\end{array}$ \\
\hline Grenada & 14 & 0 & 0 & No information reported & $\begin{array}{l}\text { IPV } \\
\text { HepB3 } \\
\text { Hib3 } \\
\text { MCV1 } \\
\text { Pol3 } \\
\text { RCV1 } \\
\text { DTP3 } \\
\text { MCV2 }\end{array}$ & $\begin{array}{l}96 \% \\
94 \% \\
94 \% \\
94 \% \\
94 \% \\
94 \% \\
92 \% \\
82 \%\end{array}$ \\
\hline Guatemala & 18 & 0 & 0 & No information reported & $\begin{array}{l}\text { IPV } \\
\text { Hib3 } \\
\text { Pol3 } \\
\text { DTP3 } \\
\text { MCV1 }\end{array}$ & $\begin{array}{l}90 \% \\
86 \% \\
79 \% \\
85 \% \\
90 \%\end{array}$ \\
\hline
\end{tabular}


Table 7 List of countries in the Americas and their vaccine production capabilities as well as their share in the exportation market (Continued)

\begin{tabular}{|c|c|c|c|c|c|c|}
\hline \multirow[t]{2}{*}{ Country } & \multirow[t]{2}{*}{$\begin{array}{l}\text { Number of vaccines } \\
\text { introduced in the EPI } \\
\text { [74] }\end{array}$} & \multirow[t]{2}{*}{$\begin{array}{l}\text { Vaccine produced } \\
\text { in own facility }\end{array}$} & \multirow[t]{2}{*}{$\begin{array}{l}\text { Local vaccine } \\
\text { production }^{\mathrm{a}}(\%)\end{array}$} & \multirow[t]{2}{*}{$\begin{array}{l}\text { Ranking in world exports of } \\
\text { vaccines for human use [75] }\end{array}$} & \multicolumn{2}{|c|}{$\begin{array}{l}{ }^{\text {b}} \text { Vaccine } \\
\text { Type and } \\
\text { target } \\
\text { achieved } \\
\text { [76] }\end{array}$} \\
\hline & & & & & $\begin{array}{l}\text { RCV1 } \\
\text { MCV2 } \\
\text { PCV3 } \\
\text { RV } \\
\text { HepB3 }\end{array}$ & $\begin{array}{l}90 \% \\
78 \% \\
88 \% \\
86 \% \\
86 \%\end{array}$ \\
\hline Guyana & 16 & 0 & 0 & 81 & $\begin{array}{l}\text { BCG } \\
\text { HepB3 } \\
\text { Hib3 } \\
\text { IPV } \\
\text { RV } \\
\text { DTP3 } \\
\text { MCV1 } \\
\text { PCV3 } \\
\text { RCV1 } \\
\text { Pol3 } \\
\text { YFV } \\
\text { MCV2 }\end{array}$ & $\begin{array}{l}99 \% \\
99 \% \\
99 \% \\
99 \% \\
99 \% \\
99 \% \\
98 \% \\
98 \% \\
98 \% \\
97 \% \\
94 \% \\
92 \%\end{array}$ \\
\hline Haiti & 9 & 0 & 0 & No information reported & $\begin{array}{l}\text { IPV } \\
\text { Pol3 } \\
\text { BCG } \\
\text { MCV1 } \\
\text { RCV1 } \\
\text { HepB3 } \\
\text { Hib3 } \\
\text { DTP3 } \\
\text { RV } \\
\text { PVC3 } \\
\text { MCV2 }\end{array}$ & $\begin{array}{l}78 \% \\
74 \% \\
73 \% \\
65 \% \\
65 \% \\
51 \% \\
51 \% \\
51 \% \\
48 \% \\
42 \% \\
41 \%\end{array}$ \\
\hline Honduras & 20 & 0 & 0 & No information reported & $\begin{array}{l}\text { IPV } \\
\text { BCG } \\
\text { RV } \\
\text { HepB3 } \\
\text { Hib3 } \\
\text { MCV1 } \\
\text { PCV3 } \\
\text { Pol3 } \\
\text { RCV1 } \\
\text { DTP3 } \\
\text { MCV2 }\end{array}$ & $\begin{array}{l}90 \% \\
88 \% \\
88 \% \\
87 \% \\
87 \% \\
87 \% \\
87 \% \\
87 \% \\
87 \% \\
87 \% \\
85 \%\end{array}$ \\
\hline Jamaica & 16 & 0 & 0 & No information reported & $\begin{array}{l}\text { BCG } \\
\text { IPV } \\
\text { HepB3 } \\
\text { Pol3 } \\
\text { DTP3 } \\
\text { Mcv1 } \\
\text { RCV1 } \\
\text { MCV2 }\end{array}$ & $\begin{array}{l}97 \% \\
97 \% \\
96 \% \\
96 \% \\
96 \% \\
94 \% \\
94 \% \\
92 \%\end{array}$ \\
\hline Mexico & 20 & 7 & 35 & 35 & $\begin{array}{l}\text { IPV } \\
\text { Hib3 } \\
\text { Pol3 } \\
\text { DTP3 } \\
\text { MCV1 } \\
\text { RCV1 } \\
\text { MCV2 } \\
\text { PCV3 } \\
\text { RV } \\
\text { HepB3 }\end{array}$ & $\begin{array}{l}84 \% \\
82 \% \\
82 \% \\
82 \% \\
73 \% \\
73 \% \\
73 \% \\
86 \% \\
82 \% \\
56 \%\end{array}$ \\
\hline Nicaragua & 15 & 4 & 26.67 & 31 & $\begin{array}{l}\text { IPV } \\
\text { MCV1 } \\
\text { Pol3 }\end{array}$ & $\begin{array}{l}99 \% \\
99 \% \\
99 \%\end{array}$ \\
\hline
\end{tabular}


Table 7 List of countries in the Americas and their vaccine production capabilities as well as their share in the exportation market (Continued)

\begin{tabular}{|c|c|c|c|c|c|c|}
\hline \multirow[t]{2}{*}{ Country } & \multirow[t]{2}{*}{$\begin{array}{l}\text { Number of vaccines } \\
\text { introduced in the EPI } \\
\text { [74] }\end{array}$} & \multirow[t]{2}{*}{$\begin{array}{l}\text { Vaccine produced } \\
\text { in own facility }\end{array}$} & \multirow[t]{2}{*}{$\begin{array}{l}\text { Local vaccine } \\
\text { production }^{\mathrm{a}}(\%)\end{array}$} & \multirow[t]{2}{*}{$\begin{array}{l}\text { Ranking in world exports of } \\
\text { vaccines for human use [75] }\end{array}$} & \multicolumn{2}{|c|}{$\begin{array}{l}{ }^{\mathrm{b}} \text { Vaccine } \\
\text { Type and } \\
\text { target } \\
\text { achieved } \\
{[76]}\end{array}$} \\
\hline & & & & & $\begin{array}{l}\text { RCV1 } \\
\text { MCV2 } \\
\text { BCG } \\
\text { HepB3 } \\
\text { Hib3 } \\
\text { PCV3 } \\
\text { RV } \\
\text { DTP3 }\end{array}$ & $\begin{array}{l}99 \% \\
99 \% \\
98 \% \\
98 \% \\
98 \% \\
98 \% \\
98 \% \\
98 \%\end{array}$ \\
\hline Panama & 25 & 1 & 4 & 34 & $\begin{array}{l}\text { BCG } \\
\text { MCV1 } \\
\text { RCV1 } \\
\text { MCV2 } \\
\text { IPV } \\
\text { PCV3 } \\
\text { RV } \\
\text { HepB3 } \\
\text { Hib3 } \\
\text { Pol3 } \\
\text { DTP3 } \\
\text { YFV }\end{array}$ & $\begin{array}{l}99 \% \\
97 \% \\
97 \% \\
97 \% \\
96 \% \\
96 \% \\
94 \% \\
88 \% \\
88 \% \\
88 \% \\
88 \% \\
7 \%\end{array}$ \\
\hline Paraguay & 26 & 0 & 0 & No information reported & $\begin{array}{l}\text { YFV } \\
\text { PCV3 } \\
\text { IPV } \\
\text { BCG } \\
\text { MCV1 } \\
\text { RCV1 } \\
\text { HepB3 } \\
\text { Hib3 } \\
\text { RV } \\
\text { DTP } \\
\text { Pol3 } \\
\text { MCV2 }\end{array}$ & $\begin{array}{l}92 \% \\
89 \% \\
88 \% \\
87 \% \\
87 \% \\
87 \% \\
86 \% \\
86 \% \\
86 \% \\
86 \% \\
84 \% \\
83 \%\end{array}$ \\
\hline Peru & 20 & 0 & 0 & No information reported & $\begin{array}{l}\text { RV } \\
\text { IPV } \\
\text { HepB3 } \\
\text { Hib3 } \\
\text { DTP } \\
\text { Pol3 } \\
\text { MCV1 } \\
\text { RCV1 } \\
\text { BCG } \\
\text { PCV3 } \\
\text { MCV2 } \\
\text { YFV }\end{array}$ & $\begin{array}{l}90 \% \\
89 \% \\
88 \% \\
88 \% \\
88 \% \\
87 \% \\
85 \% \\
85 \% \\
81 \% \\
80 \% \\
66 \% \\
57 \%\end{array}$ \\
\hline Saint Kitts and Nevis & 13 & 0 & 0 & No information reported & $\begin{array}{l}\text { BCG } \\
\text { MCV2 } \\
\text { HepB3 } \\
\text { Hib3 } \\
\text { IPV } \\
\text { MCV1 } \\
\text { RCV1 } \\
\text { Pol3 } \\
\text { DTP3 }\end{array}$ & $\begin{array}{l}99 \% \\
98 \% \\
97 \% \\
97 \% \\
97 \% \\
97 \% \\
97 \% \\
96 \% \\
96 \%\end{array}$ \\
\hline Saint Vincent and the Grenadines & 13 & 0 & 0 & No information reported & $\begin{array}{l}\text { BCG } \\
\text { MCV1 } \\
\text { Pol3 } \\
\text { RCV1 } \\
\text { MCV2 } \\
\text { HepB3 } \\
\text { Hib3 }\end{array}$ & $\begin{array}{l}99 \% \\
99 \% \\
99 \% \\
99 \% \\
99 \% \\
97 \% \\
97 \%\end{array}$ \\
\hline
\end{tabular}


Table 7 List of countries in the Americas and their vaccine production capabilities as well as their share in the exportation market (Continued)

\begin{tabular}{|c|c|c|c|c|c|c|}
\hline \multirow[t]{2}{*}{ Country } & \multirow[t]{2}{*}{$\begin{array}{l}\text { Number of vaccines } \\
\text { introduced in the EPI } \\
\text { [74] }\end{array}$} & \multirow[t]{2}{*}{$\begin{array}{l}\text { Vaccine produced } \\
\text { in own facility }\end{array}$} & \multirow[t]{2}{*}{$\begin{array}{l}\text { Local vaccine } \\
\text { production }^{\mathrm{a}}(\%)\end{array}$} & \multirow[t]{2}{*}{$\begin{array}{l}\text { Ranking in world exports of } \\
\text { vaccines for human use [75] }\end{array}$} & \multicolumn{2}{|c|}{$\begin{array}{l}{ }^{b} \text { Vaccine } \\
\text { Type and } \\
\text { target } \\
\text { achieved } \\
{[76]}\end{array}$} \\
\hline & & & & & $\begin{array}{l}\text { DTP3 } \\
\text { IPV }\end{array}$ & $\begin{array}{l}97 \% \\
96 \%\end{array}$ \\
\hline Suriname & 17 & 0 & 0 & No information reported & $\begin{array}{l}\text { IPV } \\
\text { HepB3 } \\
\text { Hib3 } \\
\text { DTP3 } \\
\text { Pol3 } \\
\text { MCV1 } \\
\text { RCV1 } \\
\text { MCV2 } \\
\text { YFV }\end{array}$ & $\begin{array}{l}82 \% \\
77 \% \\
77 \% \\
77 \% \\
76 \% \\
64 \% \\
64 \% \\
58 \% \\
57 \%\end{array}$ \\
\hline Trinidad and Tobago & 16 & 0 & 0 & 83 & $\begin{array}{l}\text { MCV1 } \\
\text { RCV1 } \\
\text { YFV } \\
\text { HepB3 } \\
\text { Hib3 } \\
\text { PCV3 } \\
\text { Pol3 } \\
\text { DTP3 } \\
\text { IPV } \\
\text { MCV2 }\end{array}$ & $\begin{array}{l}99 \% \\
99 \% \\
98 \% \\
93 \% \\
93 \% \\
93 \% \\
93 \% \\
93 \% \\
92 \% \\
92 \%\end{array}$ \\
\hline United States & 30 & 18 & 60 & 5 & $\begin{array}{l}\text { IPV } \\
\text { Hib3 } \\
\text { Pol3 } \\
\text { DTP3 } \\
\text { MCV1 } \\
\text { RCV1 } \\
\text { MCV2 } \\
\text { PCV3 } \\
\text { RV } \\
\text { HepB3 }\end{array}$ & $\begin{array}{l}97 \% \\
91 \% \\
93 \% \\
94 \% \\
90 \% \\
90 \% \\
95 \% \\
92 \% \\
74 \% \\
91 \%\end{array}$ \\
\hline Uruguay & 19 & 2 & 10.53 & No information reported & $\begin{array}{l}\text { BCG } \\
\text { IPV } \\
\text { MCV2 } \\
\text { MCV1 } \\
\text { RCV1 } \\
\text { PCV3 } \\
\text { HepB3 } \\
\text { Hib3 } \\
\text { DTP3 } \\
\text { Pol3 }\end{array}$ & $\begin{array}{l}99 \% \\
99 \% \\
99 \% \\
96 \% \\
96 \% \\
95 \% \\
94 \% \\
94 \% \\
94 \% \\
93 \%\end{array}$ \\
\hline Venezuela & 16 & 4 & 25 & No information reported & $\begin{array}{l}\text { MCV1 } \\
\text { RCV1 } \\
\text { BCG } \\
\text { YFV } \\
\text { HepB3 } \\
\text { Hib3 } \\
\text { DTP3 } \\
\text { Poli3 } \\
\text { IPV } \\
\text { MCV2 }\end{array}$ & $\begin{array}{l}93 \% \\
93 \% \\
91 \% \\
80 \% \\
64 \% \\
64 \% \\
64 \% \\
62 \% \\
55 \% \\
13 \%\end{array}$ \\
\hline
\end{tabular}

${ }^{a}$ The percentage of self-sufficiency in vaccine production is estimated as the number of different types of vaccines produced by national manufacturers as a function of the number of vaccines in use by the immunization program

${ }^{\mathrm{b}} B C G$ bacille Calmette-Guerin, HepB hepatitis B virus, DTP diphtheria, tetanus, and pertussis, MMR mumps, measles, and rubella, Hib Haemophilus influenzae type B, $H P V$ human papillomavirus, MCV vaccine meningococcal conjugate vaccine, DPT diphtheria-tetanus-pertussis 
production of generic drugs and branded products sponsored by multinational companies that focus on high-demand products [70, 73].

Finally, some of the not included countries were scarce, not clear, or came from unofficial sources, therefore not discussed in this review; nevertheless, data from most of the region's countries are displayed in Table 7.

\section{Discussion}

Vaccine manufacturing is a universal and essential activity to tackle some of the main public health problems worldwide. EPI has been successfully introduced and improved in the American continent, reducing the morbidity and mortality of essential diseases in the region. However, vaccines production has concentrated in developed countries from North America, such as

Table 8 Information about country-specific vaccines, subtype, current production/clinical trials status, comments about limitations and other limitations

\begin{tabular}{|c|c|c|c|c|c|}
\hline Country & Type of vaccine & $\begin{array}{l}\text { Leading } \\
\text { Institute }\end{array}$ & $\begin{array}{l}\text { Immunological } \\
\text { strategy }\end{array}$ & Stage of development & $\begin{array}{l}\text { Comments/limitations and } \\
\text { possible side effects }\end{array}$ \\
\hline Argentina & $\begin{array}{l}\text { Junin virus (JUNV) } \\
\text { vaccine against } \\
\text { Argentinian } \\
\text { hemorrhagic } \\
\text { fever }\end{array}$ & $\begin{array}{l}\text { National } \\
\text { Institute of } \\
\text { Human Viral } \\
\text { Diseases (ANLI } \\
\text { S), Argentina }\end{array}$ & $\begin{array}{l}\text { Cell culture with the } \\
\text { virus molecular } \\
\text { constructs [78]. }\end{array}$ & $\begin{array}{l}\text { Based on phase 3, Clinical Trial: } \\
\text { Candid\#1 vaccine against Argentine } \\
\text { hemorrhagic fever produced in } \\
\text { Argentina is authorized for } \\
\text { marketing in Argentina. } \\
\text { Immunogenicity and safety [79] } \\
\text { No Clinical Trial Registry. } \\
\text { FDA's Investigational New Drug } \\
\text { Application \#2257 }\end{array}$ & $\begin{array}{l}\text { With the use of the vaccine in high- } \\
\text { risk individuals, AHF incidence has } \\
\text { declined, but cases continue to be } \\
\text { reported [80]. }\end{array}$ \\
\hline \multirow[t]{3}{*}{ Brazil } & $\begin{array}{l}\text { Tetravalent } \\
\text { Dengue Vaccine }\end{array}$ & $\begin{array}{l}\text { Butantan and } \\
\text { the National } \\
\text { Institutes of } \\
\text { Health }(\mathrm{NIH})\end{array}$ & $\begin{array}{l}\text { Live attenuated } \\
\text { tetravalent DEN virus to } \\
\text { provide immunity to } \\
\text { each of the four } \\
\text { serotypes of DEN [81] }\end{array}$ & $\begin{array}{l}\text { NCT02406729, Phase 3, Ongoing. } \\
\text { NCT01696422, Phase } 2 \text { results } \\
\text { demonstrated safety and induced } \\
\text { robust, balanced, neutralizing } \\
\text { antibody responses against the four } \\
\text { DENV serotypes, in both naive and } \\
\text { pre-exposed volunteers, after a sin- } \\
\text { gle dose [82]. }\end{array}$ & $\begin{array}{l}\text { Limitation of the previous unique } \\
\text { vaccine approved CYD-DTV has } \\
\text { shown that age and previous expos- } \\
\text { ure status of vaccine recipients to } \\
\text { dengue virus had a significant } \\
\text { effect on the safety and efficacy of } \\
\text { the vaccine [82]. The tetravalent } \\
\text { vaccine expects to overcome this } \\
\text { limitation. }\end{array}$ \\
\hline & Zika Vaccine & $\begin{array}{l}\text { Butantan } \\
\text { Institute }\end{array}$ & $\begin{array}{l}\text { Live, DENV-vectored } \\
\text { vaccine expressing pre } \\
\text { membrane/ } \\
\text { membrane and } \\
\text { envelope proteins } \\
\text { Purified inactivated virus }\end{array}$ & Early-stage research [83] & \\
\hline & & $\begin{array}{l}\text { Bio- } \\
\text { Manguinhos }\end{array}$ & $\begin{array}{l}\text { Purified inactivated virus } \\
\text { YF17DD chimera } \\
\text { VLP } \\
\text { DNA }\end{array}$ & & \\
\hline \multirow[t]{2}{*}{ Colombia } & $\begin{array}{l}\text { Malaria SPf66 } \\
\text { vaccine }\end{array}$ & $\begin{array}{l}\text { Malaria } \\
\text { Vaccine and } \\
\text { Drug } \\
\text { Development } \\
\text { Center, } \\
\text { Colombia }\end{array}$ & $\begin{array}{l}\text { Synthetic vaccine } \\
\text { against the asexual } \\
\text { blood stages of } \\
\text { Plasmodium falciparum }\end{array}$ & $\begin{array}{l}\text { No registry in Clinicaltrials.gov } \\
\text { Results published concluded that } \\
\text { synthetic SPf66 vaccine may be } \\
\text { used as a safe and highly } \\
\text { immunogenic vaccine, suitable to } \\
\text { protect high-risk populations such } \\
\text { as children under } 5 \text { years of age resi- } \\
\text { dent in hyper- and holo-endemic } \\
\text { areas, such as Africa or some re- } \\
\text { gions of Latin America [84] }\end{array}$ & $\begin{array}{l}\text { A posterior Cochrane systematic } \\
\text { review reported no evidence for } \\
\text { protection by SPf66 vaccines against } \\
P \text {. falciparum in Africa and a modest } \\
\text { reduction in attacks of } P \text {. falciparum } \\
\text { in South America. Further research } \\
\text { with SPf66 vaccines in South } \\
\text { America or with new formulations } \\
\text { of SPf66 may be justified [85] }\end{array}$ \\
\hline & $\begin{array}{l}\text { Malaria vaccine } \\
\text { against } \\
\text { Plasmodium vivax }\end{array}$ & $\begin{array}{l}\text { Malaria } \\
\text { Vaccine and } \\
\text { Drug } \\
\text { Development } \\
\text { Center, } \\
\text { Colombia }\end{array}$ & $\begin{array}{l}\text { Vaccine derived from } \\
\text { the synthetic CS protein } \\
\text { of Plasmodium vivax }\end{array}$ & $\begin{array}{l}\text { NCT02083068, Phase II, completed, } \\
\text { no results posted }\end{array}$ & \\
\hline Mexico & $\begin{array}{l}\text { Vacuna } \\
\text { Antipoliomielítica } \\
\text { Bivalente Oral }\end{array}$ & Birmex & & $\begin{array}{l}\text { NCT01870206 } \\
\text { Phase } 3 \\
\text { Randomized Clinical Trial to Evaluate } \\
\text { Immunogenicity and Safety in } \\
\text { Mexican Newborns. Status Unknown }\end{array}$ & \\
\hline
\end{tabular}


Canada, the United States, and developing countries in Latin America. Cuba, Brazil, México, and Colombia have a self-sufficient production of $72.7,54.2 \%$; $25 \%$; and $7.7 \%$ of the national vaccine demand, respectively [32]. On the other hand, the rest of Latin American countries cannot produce vaccines or vaccine components, depending on external production to satisfy their national immunization programs. The strategies of countries who maintain public manufacturing of vaccines in Latin America include investment in technology and science, improvement of installed capacities to fulfill GMP, and developing industrial capacities with anticipated policies, in concordance with the country's needs. Besides, collaborative agreements among national institutes and different countries have demonstrated an effective strategy in vaccine manufacturing. Technology transfer programs with the private pharmaceutical industry, as the mechanisms for transferring technology and technical support, guarantee countries' capacities. Currently, Latin American countries represent a crucial vaccine market in value and volume.

Despite some of the issues in terms of resources, infrastructure, and economic investment, it is also important to emphasize that some countries are in the race to produce vaccines, especially those aimed at controlling neglected tropical diseases [77].

Although the vast majority of clinical studies on vaccines take part in North American countries such as Canada or the United States, some Latin American countries have made progress in carrying out some clinical studies to verify their vaccines' efficacy and safety (Table 8).

All local vaccine production strategies appear to be directly related to the best vaccination coverage in their countries. Some countries that have stopped producing vaccines have lowered their coverage levels, as shown by the Ecuadorian experience [86].

In contrast to Ecuador, which dropped coverage when manufacturing decreased, Nicaragua, which imports all its vaccines, has exceptionally high vaccination rates, suggesting that manufacturing is not as crucial as a wellfunded vaccination program with robust public health and political backing.

On the other hand, it is essential to understand that vaccines are not produced in most countries of the continent, and only those with stronger economies or emerging economies have managed to maintain and generate sustainable and effective production levels.

When we review the region's current situation, we realize that the countries with the most significant investment in research and development have installed capacities to produce these products with high added value. It is essential to emphasize the need for countries with little or no vaccine production to invest in personnel and to improve technological capabilities for vaccine production. This biotechnological development area will serve shortly to break out of economic dependence and shift to an economy that exports valuable raw materials at the international level.

\section{Conclusions}

This review has demonstrated the marked difference in the productive capacities of vaccines at the continental level. In the American continent, countries with great economies and adequate management of research resources such as Mexico, Canada, or the United States are the leaders in producing and exporting vaccines. In contrast, other countries with emerging economies such as Brazil, Mexico, or Argentina have local capacities installed, and they produce the much-needed vaccines to satisfy their needs and, in some circumstances, regional needs. On the other hand, many developing countries of the region do not start with their bio-industrialization and have little manufacturing capacities or few strategies to become independent in biotech dependence. However, most of the research carried out in these countries has not yet reached a level of industrial scale-up and is dependent on financing and investment by private companies.

Finally, we observe that lower or scarce vaccine production is associated with poorer vaccine rate coverages. Although many other factors are related to this situation, producing biological products in situ will improve capacities and responses, especially in new and emerging diseases.

\section{Abbreviations}

ANLIS: National Administration of Laboratories and Institute of Health; ANMA T: National Administration of Medicine, Food and Medical Technology; BCG: Bacillus Calmette-Guérin; BIOCEN: National Bio-preparations Centre; BIRMEX: General Biologic and Reactives from Mexico; CETA: Comprehensive Economic and Trade Agreement; CIGB: Center of Genetic Engineering and Biotechnology; DCVM: Developing Countries Vaccines Manufactures;

DT: Diphteria-Tetanus; DTG: Diphteria-Tetanus-Pertussis; DwPT: Diphtheria whole-cell pertussis tetanus; EPI: Expanded Program on Immunization; FIDI C: Foundation Institute of Immunology of Colombia; GMP: Good manufacturing procedures; GSK: GlaxoSmithKline; HepA: Hepatitis A; HepB: Hepatitis B; Hib-IPV: Haemophilus influenza type b, inactivated polio vaccine; HPV: Human papilloma virus; IMS: Medical Institute Sucre; IPV: Inactivated Polio vaccine; MCV: Meningococcal vaccie; MCV1: Measlescontaining- vaccine- first- dose; MCV2: Measles-containing-vaccine seconddose; MCV4: Meningococcal conjugate vaccine; Meas: Measles-only vaccine; MMR: Measles, mumps and rubella vaccine; OEC: Observatory of Economic Complexity; ONEI: National Statistics and Information Office of Cuba; OVP: Oral polio vaccine; PAHO: Pan American Health Organization; PVC: Pneumococcal conjugate vaccine; RV: Rotavirus; SII: Serum Institute of India; TECPAR: Institute of Technology of Panamá; VLP: Virus-like particle; VSV: Vesicular stomatitis virus; WHO: World Health Organization; YF: Yellow Fever

\section{Acknowledgements}

We would like to thank Alex Lister for his support while reviewing and proof-reading part of this document. 


\section{Authors' contributions}

EOP was in charge of the entire conceptualization of the project, to collect initial data and to write the draft and the final version of this manuscript. EE, NRB and JV were responsible for reviewing the latest data in the region, elaborating tables and to review the final draft. NCK and ALC were fully responsible for the vaccine development section and the figures for the manuscript as well as for the reviewing of the final version of the manuscript. The author(s) read and approved the final manuscript.

\section{Funding}

No funding was received to complete any of the stages of this investigation.

\section{Availability of data and materials}

Most of the data publicly available, nevertheless, very few databases are available, and the information is dispersed.

\section{Declarations}

\section{Ethics approval and consent to participate}

This is an observational study, therefore and according to the good clinical practices and regional legislation, no ethical approval was required.

\section{Consent for publication}

N/A.

\section{Competing interests}

The authors declare that there is no conflict of interest.

\section{Author details}

'One Health Research Group, Universidad de las Américas, Quito, Ecuador Calle de los Colimes y Avenida De los Granados, 170137 Quito, Ecuador. ${ }^{2}$ Department of Cell Biology, Physiology and Immunology, Universidad de Barcelona, Barcelona, Spain. ${ }^{3}$ Centro de Investigación Genética y Genómica, Facultad de Ciencias de la Salud Eugenio Espejo, Universidad UTE, Quito, Ecuador. ${ }^{4}$ Red Latinoamericana de Implementación y Validación de Guías Clínicas Farmacogenómicas (RELIVAF-CYTED), Quito, Ecuador.

Received: 1 September 2020 Accepted: 30 March 2021 Published online: 13 April 2021

\section{References}

1. CDC Global Health - Vaccines and Immunization. Available from: http:// www.cdc.gov/globalhealth/immunization/. Accessed 4 May 2020.

2. Ortiz-Prado E, Simbaña-Rivera K, Gómez-Barreno L, Rubio-Neira M, Guaman LP, Kyriakidis NC, et al. Clinical, molecular and epidemiological characterization of the SARS-CoV2 virus and the coronavirus disease 2019 (COVID-19), a comprehensive literature review. Diagn Microbiol Infect Dis. 2020;98:115094.

3. Plotkin SA, Plotkin SL. The development of vaccines: how the past led to the future. Nat Rev Microbiol. 2011;9(12):889-93. https://doi.org/10.1038/ nrmicro2668.

4. Baden LR, El Sahly HM, Essink B, Kotloff K, Frey S, Novak R, et al. Efficacy and safety of the mRNA-1273 SARS-CoV-2 vaccine. N Engl J Med. 2020;384:40315.

5. Chen W-H, Strych U, Hotez PJ, Bottazzi ME. The SARS-CoV-2 vaccine pipeline: an overview. Curr Trop Med Rep. 2020;7:1-4.

6. Friede M, Palkonyay L, Alfonso C, Pervikov Y, Torelli G, Wood D, et al. WHO initiative to increase global and equitable access to influenza vaccine in the event of a pandemic: supporting developing country production capacity through technology transfer. Vaccine. 2011;29:A2-7. https://doi.org/10.1016/ j.vaccine.2011.02.079

7. Milstien JB, Kaddar M, Kieny MP. The Impact Of Globalization On Vaccine Development And Availability. Health Aff (Millwood). 2015;25:4.

8. Kolehmainen J, Irvine J, Stewart L, Karacsonyi Z, Szabó T, Alarinta J, et al. J Knowl Econ. 2016;7(1):23-42. https://doi.org/10.1007/s13132-015-0289-9.

9. Smith R. Vaccines and medicines for the world's poorest: public-private partnerships seem to be essential. Br Med J Publishing Group. 2000;320: 952-3

10. Plotkin S, Robinson JM, Cunningham G, labal R, Larsen S. The complexity and cost of vaccine manufacturing - An overview. Vaccine. 2017;35(33):
4064-71 Available from: https://linkinghub.elsevier.com/retrieve/pii/S026441 OX17307703. [cited 2020 Oct 25].

11. Sinclair $A$, Latham $P$, Ellis R, Pujar NS. Vaccine production economics. In: Wen EP, , editors. Vaccine Manufacturing and Development. 20. 2015. p. 415.

12. Luyten J, Beutels P. The Social Value Of Vaccination Programs: Beyond CostEffectiveness. Health Aff (Millwood). 2016;35(2):212-8 Available from: http:// www.healthaffairs.org/doi/10.1377/hlthaff.2015.1088. [cited 2020 Oct 25]

13. Keja K, Chan C, Hayden G, Henderson RH. Expanded programme on immunization. World Health Stat Q. 1998;41(2):59-63.

14. Etienne CF. Expanded program on immunization in the Americas: 40 years. Rev Panam Salud Pública. 2017:1-2. https://doi.org/10.26633/RPSP.2017.139.

15. WHO. Global vaccine market report; 2018. p. 1-14. Available from: https:// www.who.int/immunization/programmes_systems/procurement/mi4a/pla tform/module2/MI4A_Global_Vaccine_Market_Report.pdf. [cited 2020 Jul 15]

16. BIOTECanada. Canada's vaccine industry committee. Available from: http:// www.biotech.ca/policy-matters/health/canadas-vaccine-industrycommittee/. Accessed 4 May 2020.

17. BIOTECanada. The current Canadian Vaccine Environment. 2010. Available from: http://www.biotech.ca/wp-content/uploads/2016/04/vaccines_2_2010. pdf

18. Organisation for Economic Co-operation and Development. Health Care Utilisation: Immunisation. 2019. Available from: https://stats.oecd.org/Index.a spx?Queryld=30145

19. Government of Canada. CETA benefits already visible a year after its entry into force. 2019. Available from: https://www.international.gc.ca/gac-amc/ca mpaign-campagne/ceta-aecg/year_one-premiere_annee.aspx?lang=eng

20. Government of Canada. Regulating vaccines for human use in Canada. 2020. Available from: https://www.canada.ca/en/health-canada/services/ drugs-health-products/biologics-radiopharmaceuticals-genetic-therapies/a ctivities/fact-sheets/regulation-vaccines-human-canada.htm|\#2.0

21. Industry Canada. (2013). Canada's pharmaceutical industry and prospects. Retrieved from https://www.ic.gc.ca/eic/site/lsg-. Accessed 4 May 2020.

22. eHealth. Panorama. Available from: https:/www.ehealthsask.ca/services/pa norama. Accessed 4 May 2020.

23. Government of Canada. Vaccination Coverage Goals and Vaccine Preventable Disease Reduction Targets by 2025. 2020. Available from: https://www.canada.ca/en/public-health/services/immunization-vaccinepriorities/national-immunization-strategy/vaccination-coverage-goals-va ccine-preventable-diseases-reduction-targets-2025.htm

24. BIOTECanada. Vaccines in Canada. 2016. Available from: http//mww.biotech.ca/ policy-matters/health/canadas-vaccine-industry-committee/vaccines-in-canada/

25. Coherent Market Insights. U.S. Vaccine market analysis. 2020. Available from: https:/ www.coherentmarketinsights.com/market-insight/us-vaccine-market-4011

26. Thomasnet. Top Vaccine Manufacturers and Suppliers in the USA. 2020. Available from: https://www.thomasnet.com/articles/top-suppliers/vaccinemanufacturers-and-suppliers/

27. Rubin JL, McGarry LJ, Strutton DR, Klugman KP, Pelton SI, Gilmore KE, et al. Public health and economic impact of the 13-valent pneumococcal conjugate vaccine (PCV13) in the United States. Vaccine. 2010;28(48):763443. https://doi.org/10.1016/j.vaccine.2010.09.049.

28. Export Genius. US imports data. 2019. Available from: https://www. exportgenius.in/export-import-trade-data/usa-import.php?gclid=CjwKCA jwwMn1BRAUEiwAZ_jnEo4brUVbBXw8xNNLXFII8siv7ukTHXnxkL_C-T5XEA xgTTHnd6AephoC_oQAvD_BwE

29. FDA. Vaccine Product Approval Process. 2018. Available from: https://www. fda.gov/vaccines-blood-biologics/development-approval-process-cber/va ccine-product-approval-process

30. CDC. Child \& Adolescent Immunization Schedule. 2020. Available from: https:/www.cdc.gov/vaccines/schedules/hcp/imz/child-adolescent.html

31. Tamez, S., Eibenschutz, C., Zafra, X., \& Ramírez, R. Public-private articulation in the production of vaccines in Mexico. 2016; rio de Janeiro, v. 40, n. 111:9-21.

32. Cortes M de los A, Cardoso D, Fitzgerald J, DiFabio JL. Public vaccine manufacturing capacity in the Latin American and Caribbean region: current status and perspectives. Biol J Int Assoc Biol Stand 2012;40(1):3-14.

33. Santos Jl. El programa Nacional de Vacunación: orgullo de México. Rev Fac Med UNAM. 2002;45(3):142-53.

34. Guerra S, Gutierrez J-P. The pharmaceutical market in Mexico: size, value, and concentration. Rev Panam Salud Pública Pan Am J Public Health. 2009; 26:46-50. 
35. Colombia P. Estudio de Mercado-Honduras. Análisis Del Sector Farmacéutico. 2004;5(3-4):73-9.

36. OEC. Which countries import Vaccines, human use? (2018). 2018. Available from: https://oec.world/en/visualize/tree_map/hs92/import/all/show/630022 0/2018/

37. Gobierno de la República de Honduras. 4 años de estar vigente la Ley de Vacunas en Honduras. 2018. Available from: http://www.salud.gob.hn/site/ index.php/component/k2/item/1060-4-anos-de-estar-vigente-la-ley-de-va cunas-en-honduras, Accessed 4 May 2020.

38. Janusz CB, Castañeda-Orjuela C, Aguilera IBM, Garcia AGF, Mendoza L, Díaz IY, Resch S. Examen de los costos de aplicación de la vacunación de rutinaen Honduras, Vaccine 33S. 2015;S60-S67

39. thepharmaletter. New plant to supply vaccines to Central and Latin America region. 2017. Available from: https://www.thepharmaletter.com/article/newplant-to-supply-vaccines-to-central-and-latin-america-region

40. Gavi The Vaccine Alliance. Nicaragua. 2019. Available from: https://www.ga vi.org/programmes-impact/country-hub/americas/nicaragua

41. Ministerio de Salud de Panamá. Ministerio de Salud Esquema Nacional de Vacunación. 2019 Available from: https://hn.sld.pa/wp-content/uploads/201 9/03/ESQUEMA-DE-VACUNACI\%C3\%93N2019.pdf

42. OPS Panamá. Panamá cuenta con Esquema Nacional de Vacunación actualizado para 2019. 2019. Available from: https://www.paho.org/pan/ index.php?option=com_content\&view=article\&id=1184:panama-cuenta-conesquema-nacional-de-vacunacion-actualizado-para-2019\&ltemid=442

43. Makinen M, Kaddar M, Molldrem V, Wilson L. New vaccine adoption in lowermiddle-income countries. Health Policy Plann. 2012;27(suppl_2):ii39-49.

44. Rojas M, Amador R, Posada MA, Patarroyo ME. Desarrollo y pruebas de campo de la vacuna sintética contra la malaria SPf66. Revista de La Facultad de Med. 1993;41(2):60-9.

45. Gobierno Bolivariano de Venezuela. Quimbiotec. 2010. Available from: http://www.quimbiotec.gob.ve/home.php/home.php

46. Calderón, O. U. (2010). Análisis de la Industria Farmacéutica Peruana 2010. Ensayo. CENTRUM PUCP. Tulane University. Global MBA II. Organizaciones Industriales Y Tecnológicas.

47. Castillo-Solórzano C, Marsigli C, Bravo-Alcántara P, Flannery B, Ruiz Matus C, Tambini $\mathrm{G}$, et al. Elimination of rubella and congenital rubella syndrome in the Americas. J Infect Dis. 2011;204(suppl_2):S571-8.

48. Perú 21, Diario El Comercio. INEl: Vacunación mejora, pero no alcanza estándares deseados. 2016; Available from: https://peru21.pe/lima/inei-va cunacion-mejora-alcanza-estandares-deseados-216154-noticia/

49. Zunino E. Epidemiología de la hepatitis B en Chile y esquemas de vacunación en Latinoamérica. Rev Chil Infectol. 2002;19(3):140-55.

50. Embajada de Perú en Francia. Cooperación. 2015; Available from: http:// www.embajada.pe/sites/Francia/elperuypais/Paginas/Cooperacion.aspx

51. Boadle A. Brazil to produce measles and rubella vaccine for poor countries. Reuters. 2013; Available from: https://www.reuters.com/article/us-brazil-mea sles-idUSBRE99R0IQ20131028. [cited 2020 Jul 15].

52. EFE salud. Brasil vuelve a exportar la vacuna contra la fiebre amarilla tras dos años sin ventas. 2019; Available from: https://www.efe.com/efe/a merica/sociedad/brasil-vuelve-a-exportar-la-vacuna-contra-fiebre-amarilla-tra s-dos-anos-sin-ventas/20000013-4093124\#.

53. OEC. Where does world countries import from? (2017). 2017. Available from: https://oec.world/es/visualize/tree_map/hs92/import/nic/show/3002/2017/

54. Gobierno de Bolivia. (2013). Estrategia Nacional de Medicmentos Genericos. Retrieved from http://oras-conhu.org/data/201510216276.pdf

55. Gimenez, E. (2012). El Sector farmaceutico del Paraguay. Retrieved from https://prezi.com/apb2jc6bsmtl/el-sector-farmaceutico-del-paraguay/.

56. Government of Liberia. Ministry of Health and Social Welfare Annual Report 2014. 2014. Available from: https://reliefweb.int/report/liberia/ministry-hea Ith-and-social-welfare-annual-report-2014

57. Akira di F José Luis Homma, de Quadros, Ciro. Los laboratorios públicos productores de vacunas: el nuevo paradigma. Rev Panam Salud PublicaPan Am J Public Health. 1998;4(4). Available from: https://www.scielosp.org/a rticle/rpsp/1998.v4n4/223-232/\#ModalDownloads. Accessed 4 May 2020

58. Ambrosio A, Saavedra M, Mariani M, Gamboa G, Maiza A. Argentine hemorrhagic fever vaccines. Hum Vaccin. 2011;7(6):694-700.

59. Johnson DM, Jokinen JD, Wang M, Pfeffer T, Tretyakova I, Carrion R, et al. Bivalent Junin \& Machupo experimental vaccine based on alphavirus RNA replicon vector. Vaccine. 2020;38(14):2949-59. Available from: http://www. sciencedirect.com/science/article/pii/S0264410X20302656. https://doi.org/1 0.1016/j.vaccine.2020.02.053.
60. United Nations. Local production of pharmaceuticals and related technology transfer in developing countries. 2016. Available from: https:// unctad.org/system/files/official-document/diaepcb2011d7_en.pdf

61. Berneck BS, Rockstroh A, Fertey J, Grunwald T, Ulbert S. A recombinant Zika virus envelope protein with mutations in the conserved fusion loop leads to reduced antibody cross-reactivity upon vaccination. Vaccines. 2020;8(4): 603. https://doi.org/10.3390/vaccines8040603.

62. infobae. ¿Más vacunas por la boca? Investigadores argentinos desarrollaron una plataforma para producir vacunas orales. 2020; Available from: https:// www.infobae.com/salud/2019/02/01/mas-vacunas-por-la-boca-investiga dores-argentinos-desarrollaron-una-plataforma-para-producir-vacunas-ora les/. Accessed 4 May 2020.

63. CONICET. Tres avances argentinos en vacunas. 2012. Available from: https:// www.conicet.gov.ar/tres-avances-argentinos-en-vacunas/

64. inofabae. Identifican un nuevo mecanismo que regula a una proteína clave del virus del papiloma humano. 2020; Available from: https://www.infobae. com/salud/ciencia/2020/01/23/identifican-el-mecanismo-que-regula-a-unaproteina-clave-del-virus-del-papiloma-humano/

65. inofabae, salud. Científicos argentinos crearon una exitosa vacuna contra la enfermedad de Chagas. 2017 Available from: https://www.infobae.com/sa lud/2017/04/11/cientificos-argentinos-crearon-una-exitosa-vacuna-contra-laenfermedad-de-chagas/

66. Pallarés HM, Navarro GSC, Villordo SM, Merwaiss F, de Borba L, Ledesma MMGL, et al. Zika Virus Subgenomic Flavivirus RNA Generation Requires Cooperativity between Duplicated RNA Structures That Are Essential for Productive Infection in Human Cells. J Virol. 2020;94(18):1-20.

67. Uruguay smart services pharma \& Health. Industria Farmacéutica. 2014. Available from: https://www.smarttalent.uy/innovaportal/file/861/1/ industria_farmaceutica.pdf

68. PHO. La Directora de OPS elogio accionar de Uruguay ante la Pandemia de Influenza A H1N1. 2016. Available from: https://www.paho.org/uru/index. php?option=com_content\&view=article\&id=72:la-directora-ops-elogio-a ccionar-uruguay-ante-pandemia-influenza-h1n1\&ltemid=233

69. Ortiz-Prado E, Galarza-Maldonado, Hernandez P, iturralde A. Conjugate vaccines and pneumococcal disease in Ecuador". vacunas. 2014. p. 1-63.

70. Ortiz-Prado E. Mercado Farmaceutico Ecuatoriano. 1st ed. Quito, Ecuador: Udla Ediciones; 2018. 318 p. (-logía; vol. 1).

71. El Comercio.(2018). Ecuador tiene 19 vacunas básicas para combatira las enfermedades. Retrieved from: https://www.elcomercio.com/tendencias/sa lud/ecuador-19-vacunas-basicas-combatir.html.

72. PAHO/MSP. Evaluación de la Estrategia nacional de inmunizaciones, Ecuador 2017. 2017. Available from: https://www.paho.org/ecu/index. php?option=com_docman\&view=download\&alias=673-evaluacion-de-laestrategia-nacional-de-inmunizaciones-ecuador-2017\&category_slug= inmunizaciones\&ltemid=599

73. Russell SN, Millar HH. Competitive priorities of manufacturing firms in the Caribbean. IOSR J Bus Manag. 2014;16(10):72-82. https://doi.org/10.9790/4 $87 X-161017282$.

74. World Health Organization. WHO vaccine-preventable diseases: monitoring system. 2020 global summary. 2020. Available from: https://apps.who.int/ immunization monitoring/globalsummary/schedules

75. ITC. Trade Map. 2019. Available from: https://www.trademap.org/Index.aspx

76. Samantha Vanderslott, Bernadeta Dadonaite, Max Roser. Vaccination. 2019 Available from: https://ourworldindata.org/vaccination

77. Kantor IN. Dengue, zika, chikungunya and the development of vaccines. Medicina (Mex). 2018;78(1):23-8.

78. Ambrosio AM, Mariani MA, Maiza AS, Gamboa GS, Fossa SE, Bottale AJ. Protocol for the production of a vaccine against argentinian hemorrhagic fever. In: Methods in Molecular Biology. Humana Press Inc.; 2018. p. 305-329.

79. Enria DA, Ambrosio AM, Briggiler AM, Feuillade MR, Crivelli E, Study Group on Argentine Hemorrhagic Fever Vaccine. [Candid\#1 vaccine against Argentine hemorrhagic fever produced in Argentina. Immunogenicity and safety]. Medicina (Mex). 2010;70(3):215-222.

80. Zeitlin L, Geisbert JB, Deer DJ, Fenton KA, Bohorov O, Bohorova N, et al. Monoclonal antibody therapy for Junin virus infection. Proc Natl Acad Sci U S A. 2016;113(16):4458-63. https://doi.org/10.1073/pnas.1600996113.

81. Precioso AR, Palacios R, Thomé B, Mondini G, Braga P, Kalil J. Clinical evaluation strategies for a live attenuated tetravalent dengue vaccine. Vaccine. 2015;33(50):7121-5. https://doi.org/10.1016/j.vaccine.2015.09.105.

82. Kallas EG, Precioso AR, Palacios R, Thomé B, Braga PE, Vanni T, et al. Safety and immunogenicity of the tetravalent, live-attenuated dengue vaccine 
Butantan-DV in adults in Brazil: a two-step, double-blind, randomised placebo-controlled phase 2 trial. Lancet Infect Dis. 2020;20(7):839-50. https://doi.org/10.1016/S1473-3099(20)30023-2.

83. Poland GA, Ovsyannikova IG, Kennedy RB. Zika Vaccine Development: Current Status. Vol. 94, Mayo Clinic Proceedings. Elsevier Ltd; 2019. p. $2572-$ 2586.

84. Patarroyo G, Franco L, Amador R, Murillo LA, Rocha CL, Rojas M, et al. Study of the safety and immunogenicity of the synthetic malaria SPf66 vaccine in children aged 1-14 years. Vaccine. 1992;10(3):175-8. https://doi.org/10.1016/ 0264-410X(92)90008-8.

85. Graves PM, Gelband H. Vaccines for preventing malaria (SPf66). Cochrane Database Syst Rev. 2006;19;2006(2):1-27.

86. MSP/PAHO. Estrategia Nacional de Inmunizaciones, Ecuador 2017. 2018 Available from: https://www.paho.org/ecu/index.php?option=com_docma n\&view=download\&alias=673-evaluacion-de-la-estrategia-nacional-deinmunizaciones-ecuador-2017\&category_slug=inmunizaciones\&ltemid=599

\section{Publisher's Note}

Springer Nature remains neutral with regard to jurisdictional claims in published maps and institutional affiliations.

Ready to submit your research? Choose BMC and benefit from:

- fast, convenient online submission

- thorough peer review by experienced researchers in your field

- rapid publication on acceptance

- support for research data, including large and complex data types

- gold Open Access which fosters wider collaboration and increased citations

- maximum visibility for your research: over $100 \mathrm{M}$ website views per year

At BMC, research is always in progress.

Learn more biomedcentral.com/submissions 